\begin{tabular}{|l|l|l|l|l|l|}
\hline MUNIBE Antropologia-Arkeologia & $n^{\circ} 66$ & $163-184$ & DONOSTIA & 2015 & ISSN 1132-2217 • eISSN 2172-4555 \\
\hline
\end{tabular}

\title{
Wild carnivore and wild bird deposits in an agro-pastoral community during the Bronze Age: Can Roqueta II (northeast Iberian Peninsula)
}

\section{Depósitos de carnívoros y aves salvajes en una comunidad agrícola-ganadera de la Edad del Bronce: Can Roqueta II (nordeste de la Península Ibérica)}

PALABRAS CLAVES: Bronce Antiguo-Medio, estructuras funerarias, ofrendas de animales salvajes, complejidad social y ritual. GAKO-HITZAK: Lehen Brontze Aroa, hileta-egiturak, animalia basatien eskaintzak, gizarte eta erritu mailako konplexutasuna. KEY WORDS: Early-Middle Bronze Age, funerary structures, wild animal offerings, social and ritual complexity.

\section{Silvia ALBIZUR(1), Julià MAROTO(2), Jordi NADAL(3), Tona MAJÓ(4),
Antonio SÁNCHEZ MARCO(5), Xavier CARLU'S(6), Alba RODRIGUEZ(7) \& Antoni PALOMO(8)}

\section{RESUMEN}

En este artículo se presentan los resultados de los análisis de animales salvajes depositados en diversas estructuras funerarias del Sector II de Can Roqueta en Cataluña (Bronce Antiguo-Medio). En general los depósitos intencionales de animales en un contexto funerario proporcionan una aproximación al estudio de la actividad ritual y de las creencias, especialmente en aquellas comunidades agro-pastorales donde los animales domésticos son los elementos básicos para la subsistencia y la creación de recursos.

En este caso la identificación taxonómica indica la importancia de los animales domésticos seguramente debido a su papel en la economía, así como su uso en ofrendas alimentarias y también en ofrendas simbólicas que manifiestan el estatus de los muertos. Por el contrario, el estudio tafonómico indica la escasez de animales salvajes depositados intencionalmente -seis aves y dos carnívoros-y muestra el uso diferencial de estas especies respecto a las domésticas, ya que mientras los animales importantes en la alimentación humana fueron normalmente dispuestos como ofrendas de comida para los difuntos, los animales salvajes parecen estar más estrechamente relacionados con símbolos de la vida o totémicos.

\section{LABURPENA}

Artikulu honetan, Kataluniako Can Roquetako II. sektoreko (Lehen Brontze Aroa) hileta-egitura ugarietan utzitako animalia basatien azterketako emaitzak azaltzen dira. Oro har, hileta-testuinguru bateko animalien gordailu intentzionalek jarduera erritualaren eta sinesmenen ikerketara gerturatzea eskaintzen dute, eta bereziki etxe-abereak baliabideak sortzeko eta iraupenerako oinarrizko elementuak diren nekazaritzako eta artzaintzako komunitateetan

Kasu honetan, identifikazio taxonomikoak agerian uzten du etxe-abereek zuten garrantzia eta, seguru asko, ekonomian betetzen zuten rola eta elikagaien ofrendetan zuten erabilera direla eta, baina baita hildakoen estatusa agerian uzten zutelako ofrenda sinbolikoetan ere. Aldiz, ikerketa tafonomikoak modu intentzionalean utzitako animalia basati gutxi dagoela adierazten du (sei hegazti eta bi karniboro) eta espezie horien erabilera diferentziala erakusten du etxekoekin alderatuta; izan ere, gizakiaren elikadurarako animalia garrantzitsuak, gehienetan, hildakoentzako janari-eskaintza gisa jartzen zituzten, baina animalia basatiek, itxuraz, lotura estuagoa dute bizitzaren sinboloekin edo totemikoekin.

\section{ABSTRACT}

The results of analyses of wild animals in various funerary structures from Sector II of Can Roqueta (Early-Middle Bronze Age) in Catalonia are presented in this article. In general, animal deposits in a funerary context provide an approach to the study of ritual activity and beliefs, especially in agro-pastoral communities where domestic animals are the basic elements of subsistence and the creation of resources.

In this case, taxonomic identification indicates the importance of domestic animals due to their role in the economy, as well as their use in food and symbolic offerings and as a manifestation of the power of the dead. By contrast, a taphonomic study indicates the scarcity of wild animal deposits - six birds and two carnivores - and shows the differential use of these species, which are perhaps more closely related to life symbols or totemic symbols.

(1) SERP, Departament de Prehistòria, Història Antiga i Arqueologia, Universitat de Barcelona, Montealegre 6-8, 08001 Barcelona, Catalonia, Spain (silvia.albizuri@upc.edu, project 2014SGR108; jnadal@uoc.edu, projects 2014SGR108 and HAR2014-55131).

(2) Departament d'Història i Història de l'Art, Universitat de Girona, Ferrater Mora 1, 17071 Girona, Catalonia, Spain (julia.maroto@udg.edu, project HAR2013-48784-C3-2-P).

(3) Archaeom, Departament de Prehistòria, Universitat Autònoma de Barcelona, 08193 Bellaterra, Catalonia, Spain (tonamajo@gmail.com)

(4) Institut Català de Paleontologia, Campus UAB, 08193 Bellaterra, Catalonia, Spain (antonio.sanchez@icp.cat).

(5) Archaeologist and draftsman, de Regàs 47, 08203 Sabadell, Catalonia, Spain (xcarlusmartin@gmail.com).

(6) Museu de Sant Cugat, de l'Om 1, 08172 Sant Cugat del Vallès, Catalonia, Spain (albarl@lamalla.net).

(7) Departament de Prehistòria, Universitat Autònoma de Barcelona, 08193 Bellaterra, Catalonia, Spain (antonipalomo@gmail.com). 


\section{1.- INTRODUCTION}

This paper presents an analysis of intentional deposits of wild carnivores and wild birds from the InitialBronze Age site of Can Roqueta II, in northeast Iberian Peninsula, which were found in a funerary context together with various intentional domestic animal deposits that have been studied in a previous work (ALBIZURI, 2011a). The Initial Bronze Age is used in Catalonia to cover the duration of the Bronze Age until the Late Bronze Age, i.e. between 2100 and $1300 \mathrm{cal}$ BC (MAYA, 1992). The wild-animal remains in question are not abundant, yet they are of great archaeological significance.

Archaeological excavation and archaeozoological analysis have enabled us to ascribe an intentional ritual character to a good part of the wild animal remains recorded in the funerary area, although the presence of others is interpreted as intrusive or casual.

In social archaeozoology, the identification and analysis of these deposits (henceforth referred to as "associated bone groups" or ABGs, sensu MORRIS, 2010, 2011) provide an approach to the study of ritual activity and beliefs, taking us beyond mere palaeoeconomic reconstruction.

These deposits are common in European Neolithic sites in burial and domestic contexts. They are stereotyped in form and are present in very diverse geographical areas of the world; according to present-day ethnographical evidence they are associated with rites of passage such as birth, puberty, marriage or death (GENNEP, 1909; LEWIS, 1980). The sacrifice of animals constitutes the main act of communication between society and the forces invoked. Such rituals are often intended to manipulate or be part of a dialogue with supernatural powers (BRADLEY, 2005). Among day-to-day activities they can also have the function of protecting the home and fostering fertility (CUNLIFFE, 1993).

The archaeozoological analysis of Can Roqueta II (ALBIZURI, 2011a) re-evaluates the role of funerary animal offerings as a powerful tool for sociocultural analysis. These offerings may be considered a reflection of the belongings of the deceased person and as such they bring to light social asymmetries, especially in those populations where domestic animals and crops constitute the basic elements of subsistence and the creation of resources. They also provide grounds for hypotheses on how death was understood and managed. They yield insights into the role of the animal in society and may refer us to totemic symbols and others associated with the underworld.

Special animal deposits have been studied at sites in the Iberian Peninsula from the 4th millennium BC (LIZCAINO PRESTEL et al., 1991-92; MÁRQUEZ, 2004, 2006; CÁMARA et al., 2008, 2010) and are characterized by the importance of domestic animals. During the Bronze Age in the 2nd millennium BC sheep and goats, cows, pigs and dogs are the best-represented (Equip Minferri, 1997; PINGEL et al., 2003; POZO et al., 2004; ARANDA \& ESQUIVEL, 2007; BLASCO et al., 2007; ALBIZURI, 2011a;
BLASCO et al., 2011; NIETO et al., 2014) and are characterized by the importance of sheep and goat, and chicken during the Iron Age in 1st millennium BC (MIRÓ \& MOLIST, 1990; MIRÓ, J.M., 1993; CASTAÑOS, 1994; CODINA et al., 2009; ALBIZURI, 2011b; ALBIZURI et al., 2015). These were normally deposited in pits or in funerary structures. Complete and partial skeletons of animals have been recovered, both in anatomical connection and as isolated remains. They are basically associated with ritual sacrifice and with offerings of a funerary nature; in exceptional cases, such as that of Can Roqueta, wild species are also documented.

\section{2.- SITE BACKGROUND}

The sector of Can Roqueta II forms part of the site of Can Roqueta, which is located in Sabadell at a distance of just $30 \mathrm{~km}$ from Barcelona in the coastal area of the Mediterranean (Figure 1). This site of ongoing settlement from the Neolithic to the Middle Ages is classified as a pit field, comprising domestic and funerary and ritual pits (PALOMO \& RODRÍGUEZ, 2004; CARLÚS et al., 2008). The area is situated on the sandy and clayey soils surrounding the basin of the River Ripoll 150 to 200 m above sea level.

In the northeast of the Iberian Peninsula, the period under study falls generically between 2000-1300 cal BC, and the radiocarbon datings of Can Roqueta II indicate a chronology around the midpoint of this time period, with chronological limits of 2153-1734 cal BC and 1638-1435 cal BC (2 Sigma calibrated result, 95\% probability; 3590 \pm 90 BP UBAR-698, $3265 \pm 45$ BP UBAR-799) (CARLÚS et al., 2008).

A total of 121 pits have been documented, at an altitude of ca. $180 \mathrm{~m}$ and over a surface area of 11 ha (Figure 1). The site was occupied by agricultural and livestock groups that developed good-quality binary bronzes (copper and tin) (ROVIRA, 2006). Noteworthy in this context is the presence of pottery items for storage and cooking, saddle querns, crucibles, moulds and smelting remains (Figure 2).

Pits/silos have been recorded containing material associated with dwelling, feeding, production and storage and with funerary and ritual uses. The funerary structures are numerous. Normally pits/silos are reused in this capacity, sometimes modified by opening one or several niches. The latter structures contain a large number of inhumations. Other semi-excavated dwelling structures have been documented - pit-houses - some of which display great functional complexity, containing rubbish, household materials and human remains. Finally, there are also structures that contain animal offerings without having human remains.

The results of archaeozoological studies from the excavation seasons of 1999 and 2000 show that of a total of 8698 animal remains, 4881 remains were concentrated in the 47 funerary structures of 49 recorded in the central area of the site (Table 1). 

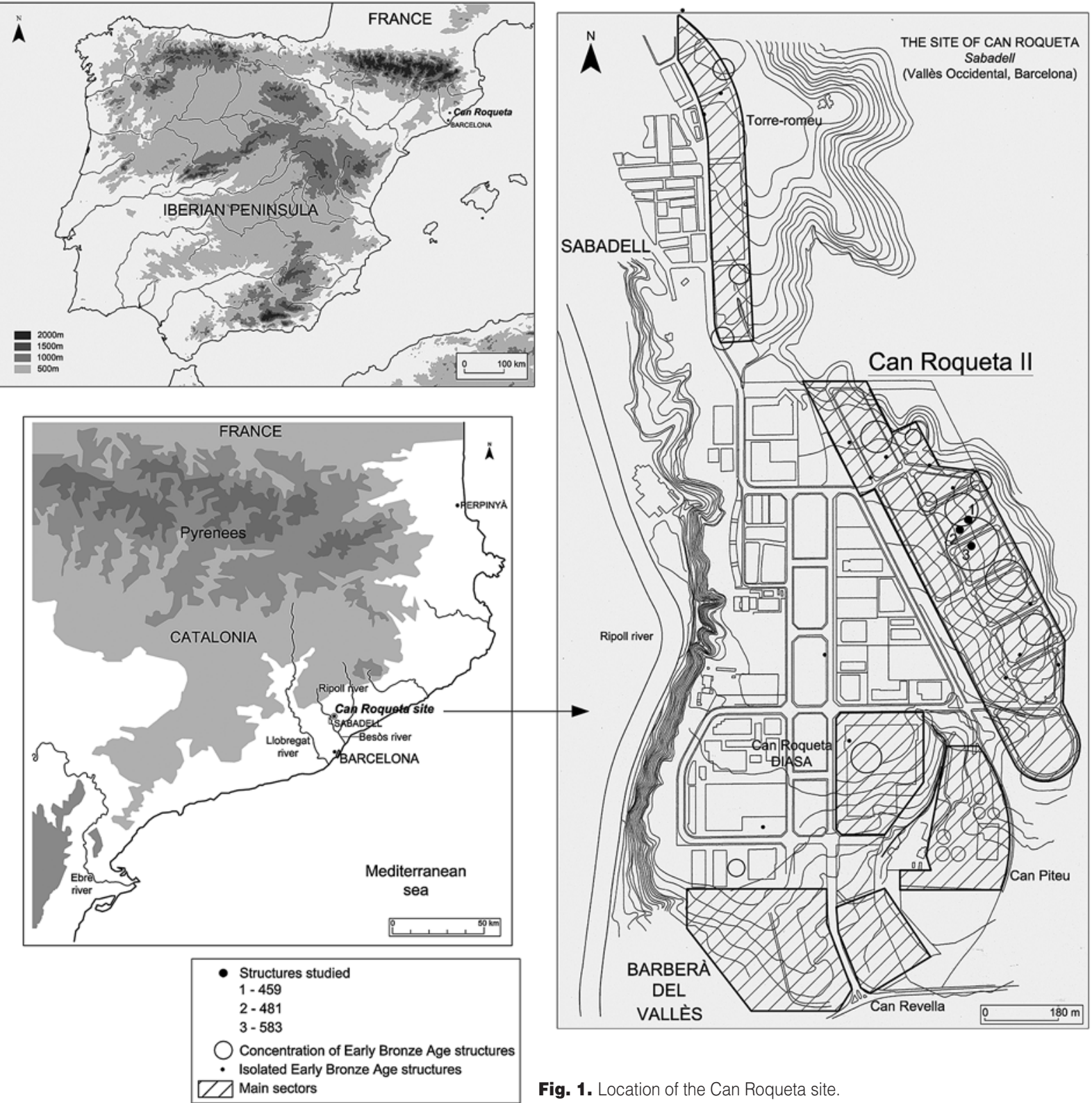

Fig. 1. Location of the Can Roqueta site.

\begin{tabular}{|l|c|c|c|c|c|c|c|}
\hline & N & $\begin{array}{c}\text { With } \\
\text { fauna }\end{array}$ & $\begin{array}{c}\text { Without } \\
\text { fauna }\end{array}$ & TNB & IS & $\begin{array}{c}\text { Remains } \\
\text { of wild } \\
\text { carnivores }\end{array}$ & $\begin{array}{c}\text { Remains } \\
\text { of wild } \\
\text { birds }\end{array}$ \\
\hline Funerary & 49 & 47 & 2 & 4881 & 2886 & 201 & 42 \\
\hline Ritual (additional intallations) & 12 & 12 & 0 & 1661 & 1241 & 0 & 0 \\
\hline Questionable interpretation & 5 & 5 & 0 & 1322 & 780 & 1 & 0 \\
\hline Pits of domestic use & 50 & 33 & 17 & 834 & 229 & 0 & 0 \\
\hline Total studied & $\mathbf{1 1 6}$ & $\mathbf{9 7}$ & $\mathbf{1 9}$ & $\mathbf{8 6 9 8}$ & $\mathbf{5 1 3 6}$ & $\mathbf{2 0 2}$ & $\mathbf{4 2}$ \\
\hline Eroded and not studied structures & 5 & & & & & & \\
\hline Total excavated & $\mathbf{1 2 1}$ & & & & & & \\
\hline
\end{tabular}

Table 1: Structures documented in the Initial Bronze Age of Can Roqueta II, indicating the Total Number of Bones recovered (TNB) and the number of bones of Identifiable Species (IS). 


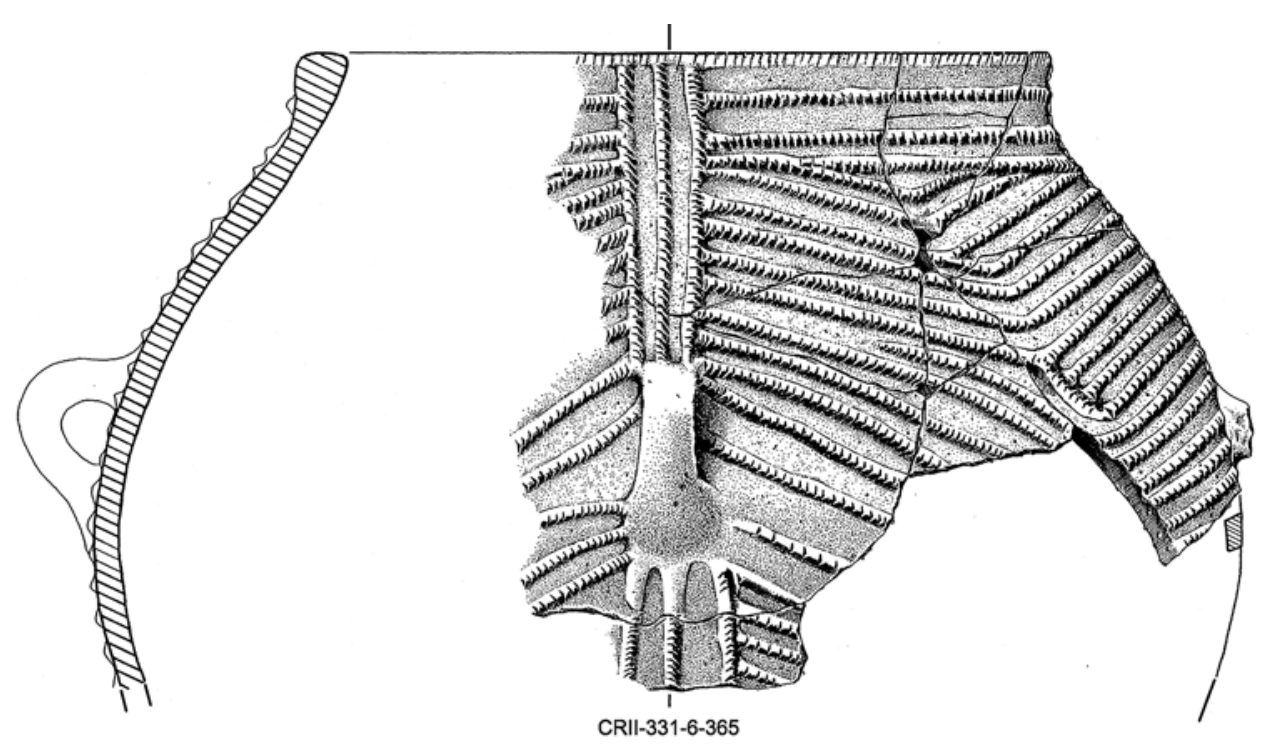

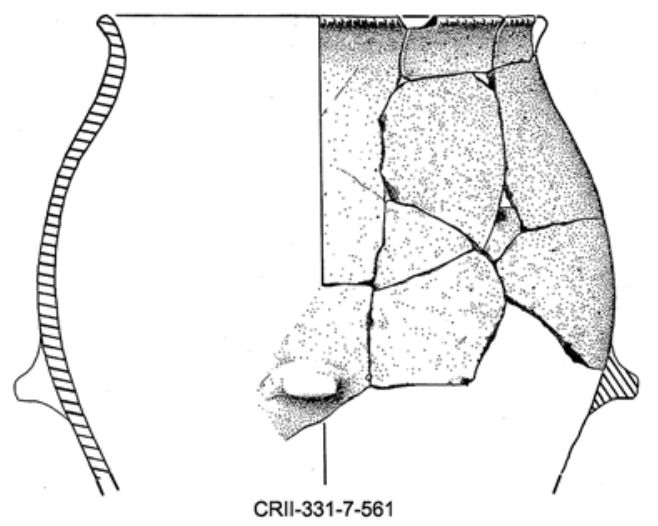
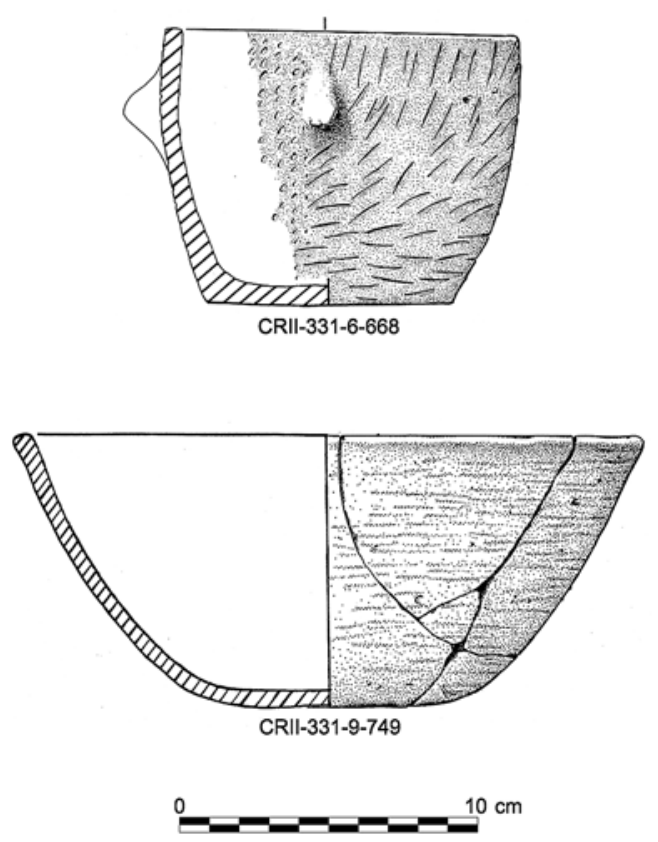

Fig. 2. The Early-Middle Bronze Age of Can Roqueta II. Pottery vessels.
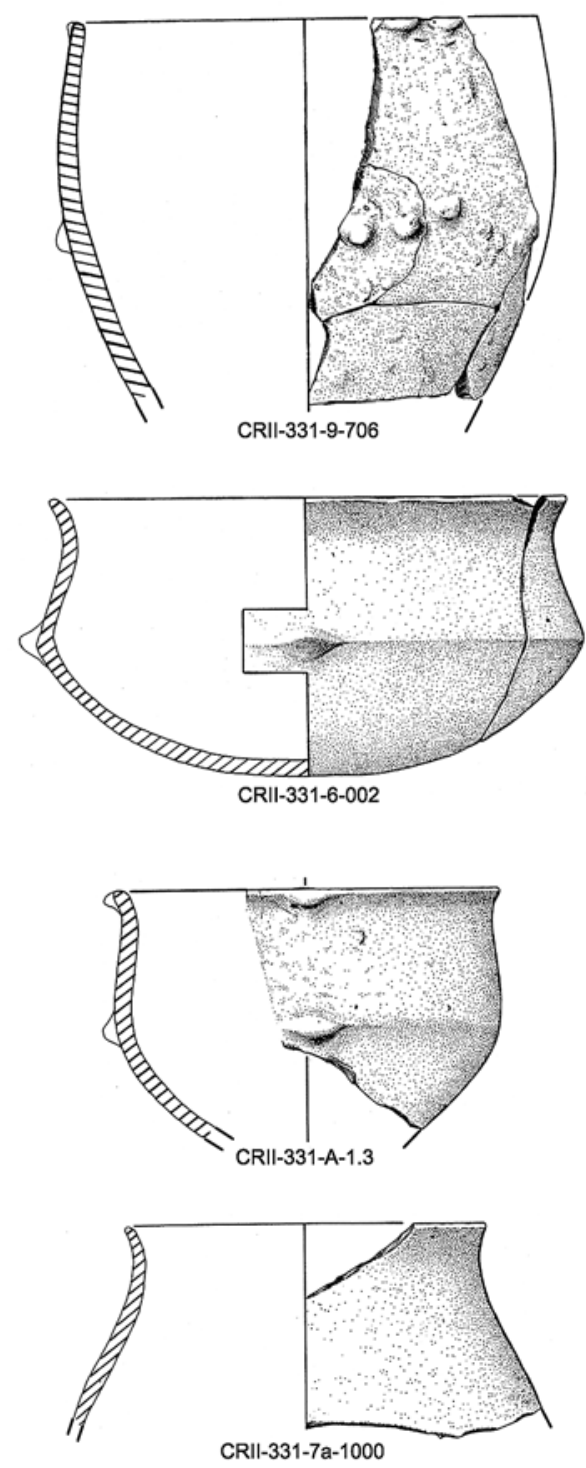
The predominant presence of five domestic species was established (Bos taurus, Sus domesticus, Ovis aries, Capra hircus, Canis familiaris) (Table 2), related in particular with farming and pastoral activity. Among these we include the dog, which should doubtless be interpreted as a crucial tool in watching over and controlling the flocks and herds. In addition, there are eight species including carnivores, lagomorphs, insectivores and wild birds (Vulpes vulpes, Meles meles, Oryctolagus cuniculus, Erinaceus europaeus, Milvus milvus, Corvus corone/frugilegus, Alectoris rufa, Fulica atra) and also various wild vertebrate taxa that are not classified to species level: carnivores, lacertids, ophidians and anuran amphibians. Further, we have found two remains that are difficult to determine but could be classifiable as wolf according to the metric data (Canis cf. lupus).

The identifiable bones from kitchen waste and/or food remains indicate livestock farming based mainly on the rearing of cattle (48.9\% NISP) and sheep and goats (32.3\%), followed by pigs (18.8\%). By contrast with funerary and ritual structures, there is no record of wild species or dogs, which only appear in tombs or in pits with ritual activity. Dogs played an important role in the economy, since as well as being used to look after the herds and flocks, they were also used in weight-bearing tasks, as indicated by various pathologies associated with stress in the lumbar and thoracic areas (ALBIZURI et al., 2011).
In 49 funerary structures 172 people were interred in either primary or secondary form; $45 \%$ of these correspond to infants and juveniles. In these structures ABGs associated with human remains are recorded, often within the same stratigraphic unit. These should be interpreted as food and as symbolic offerings. In these structures domestic species predominate and are represented by the anatomical elements richest in meat. In terms of frequency, they appear in the opposite order to their importance in the herd structure: first pigs, followed by sheep and goats, and then by dogs and cattle (Table 2)

A second group of 12 additional installations without human remains can also be distinguished. These are classified as ritual in character because they contain ABGs and are located within a few metres (between $1 \mathrm{~m}$ and $10 \mathrm{~m}$ ) of the funerary structures. In these structures only domestic species were deposited intentionally. They appear in the following order: pigs, dogs, sheep and goats, cattle (Table 3)

The stratigraphic units with multiple non-simultaneous burials or with $A B G$ s lead us to infer that both types of pit were probably planned for diverse funerary uses, or in any case for ritual activity.

The evidence from burials and house architectures and materials indicates an egalitarian social structure, although among the tombs with a maximum of two inhuma-

\begin{tabular}{|l|c|c|c|c|c|c|c|c|}
\hline & NISP & \%NISP & MNI & \%MNI & $\begin{array}{c}\text { Complete } \\
\text { MNI }\end{array}$ & $\begin{array}{c}\text { Partial } \\
\text { MNI }\end{array}$ & $\begin{array}{c}\text { Skull } \\
\text { MNI }\end{array}$ & $\begin{array}{c}\text { Isolated } \\
\text { bones MNI }\end{array}$ \\
\hline Ovis aries, Capra hircus (ovicaprids) & 787 & 26.8 & 87 & 33.7 & 2 & 6 & 3 & 76 \\
\hline Bos taurus (cattle) & 245 & 8.4 & 78 & 30.2 & & & 5 & 73 \\
\hline Sus domesticus (pig) & 961 & 32.8 & 59 & 22.9 & 11 & 4 & & 44 \\
\hline Canis familiaris (dog) & 767 & 26.1 & 26 & 10.1 & 6 & & 6 & 14 \\
\hline Canis cf. lupus (large canid) & 2 & 0.1 & 1 & 0.4 & & & & 1 \\
\hline Vulpes vulpes (fox) & 130 & 4.4 & 1 & 0.4 & 1 & & & \\
\hline Milvus milvus (red kite) & 33 & 1.1 & 3 & 1.2 & & 1 & & 2 \\
\hline Corvus corone/frugilegus (carrion crow) & 5 & 0.2 & 1 & 0.4 & & 1 & & \\
\hline Alectoris rufa (red-legged partridge) & 1 & 0.0 & 1 & 0.4 & & & & 1 \\
\hline Fulica atra (eurasian coot) & 3 & 0.1 & 1 & 0.4 & & & 1 & 2 \\
\hline Total & $\mathbf{2 9 3 4}$ & & $\mathbf{2 5 8}$ & & $\mathbf{2 0}$ & $\mathbf{1 2}$ & $\mathbf{1 5}$ & $\mathbf{2 1 3}$ \\
\hline
\end{tabular}

Table 2: Intentional animal deposits in funerary structures, indicating the Number of Identified Specimens (NISP) and the Minimum Number of Individuals $(\mathrm{MNI})$

\begin{tabular}{|l|c|c|c|c|c|c|c|c|}
\hline & NISP & \%NISP & MNI & \%MNI & $\begin{array}{c}\text { Complete } \\
\text { MNI }\end{array}$ & $\begin{array}{c}\text { Partial } \\
\text { MNI }\end{array}$ & $\begin{array}{c}\text { Skull } \\
\text { MNI }\end{array}$ & $\begin{array}{c}\text { Isolated } \\
\text { bones MNI }\end{array}$ \\
\hline Ovis aries, Capra hircus (ovicaprids) & 88 & 7.1 & 12 & 18.2 & & 2 & 10 \\
\hline Bos taurus (cattle) & 56 & 4.5 & 20 & 30.3 & & & 1 & 19 \\
\hline Sus domesticus (pig) & 623 & 50.3 & 18 & 27.3 & 4 & 2 & 2 & 10 \\
\hline Canis familiaris (dog) & 472 & 38.1 & 16 & 24.2 & 5 & 2 & 3 & 6 \\
\hline Total & $\mathbf{1 2 3 9}$ & $\mathbf{1 0 0}$ & $\mathbf{6 6}$ & $\mathbf{1 0 0}$ & $\mathbf{9}$ & $\mathbf{6}$ & $\mathbf{5}$ & $\mathbf{4 6}$ \\
\hline
\end{tabular}

Table 3: Domestic anima deposits in ritual structures (additional intallations) 
tions differences can be observed possibly associated with social and family status: some of them do not contain faunal deposits, whereas in others, normally of infants, a few remains of one or two animals are recovered, and in $24.5 \%$ there are collections of more than eight whole or partial animals.

\section{3.- MATERIAL AND METHODS}

This paper is based on the results of an analysis of funerary, ritual and questionable interpretation structures where wild species were found. A total of 1333 remains of wild species are analysed.

In the present analysis we have taken into account those wild animals that might potentially be of anthropic interest and for which there exist precedents of human use in the archaeological record. For this reason, various small-sized animals are included. By contrast, we have left out of account the rest of what is commonly known as the microfauna: rodents, small insectivores, small gastropods, etc.

On the basis of the taphonomic and archaeozoological study, 174 remains of wild canids and wild birds have been interpreted as intentional deposits (Table 2) and the presence of the remaining wild animals has been regarded as intrusive or casual (Table 4).

The set of arguments or criteria followed in analysing the ABGs of Can Roqueta II are those proposed by a variety of authors for different periods and geographical areas, allowing distinctions to be drawn with respect to kitchen waste and casual or hygienic deposits (DAVIS \& PAYNE, 1993; JEUNESSE, 2001; KANSA \& CAMPBELL, 2004; MOUTON, 2004, 2005; DAVIS, 2008; MÉNIEL, 2008; MORRIS, 2010, 2011; D'IATCHENKO \& DAVID, 2010; RUSSELL, 2010). The criteria are as follows:

1. More than one animal in anatomical connection.

2. Structured lay-out, in some cases items in anatomical connection and whole animals.

\begin{tabular}{|l|c|c|c|c|}
\hline & NISP & \%NISP & MNI & \%MNI \\
\hline Meles meles (badger) & 29 & 2.5 & 1 & 2.9 \\
\hline Vulpes vulpes (fox) & 1 & 0.1 & 1 & 2.9 \\
\hline Undetermined Carnivora & 40 & 3.5 & 2 & 5.7 \\
\hline Oryctolagus cuniculus (rabbit) & 249 & 21.5 & 8 & 22.9 \\
\hline Erinaceus europaeus (hedgehog) & 13 & 1.1 & 1 & 2.9 \\
\hline Lacerta sp. (lizard) & 270 & 23.3 & 8 & 22.9 \\
\hline Serpentes (snake) & 519 & 44.8 & 7 & 20.0 \\
\hline Anura (frogs and toads) & 38 & 3.3 & 7 & 20.0 \\
\hline Total & $\mathbf{1 1 5 9}$ & $\mathbf{1 0 0}$ & $\mathbf{3 5}$ & $\mathbf{1 0 0}$ \\
\hline
\end{tabular}

Table 4: Remains of animals whose presence is considered intrusive or casual in funerary structures or additional installations.
3. For the most part, selection of domestic species as meat offerings associated with the importance of the deceased persons. Among the wild species, predominance of dangerous and powerful or symbolic species.

4. Appearance of items with high meat content, and with low fracture indices. Identificatory anatomical parts of the animals are also recorded, such as crania and distal extremities.

5. The selection of the right or left part is of symbolic significance in ritual offerings.

6. The selection of a particular sex or age.

\section{Association with or proximity to human remains.}

The quantification of individuals was carried out for each structure on the basis of the NISP (number of identifiable specimens) and the $\mathrm{MNI}$ (minimum number of individuals) in accordance with the criteria proposed by POPLIN (1976).

A macroscopic and microscopic study of the bone surface was carried out with the intention of establishing the guidelines followed in the quartering and dismemberment of the animals, as well as possible alterations produced by agents that may have affected the bone surface (BLUMENSCHINE et al., 1996). The presence of potentially intrusive animals, as well as the displacements of the animals in anatomical connection, has been studied in order to assess the bioturbation and the degree of closure and protection provided by the structures, as well as the different moments of funerary activity.

Post-depositional surface modifications were also recorded, including carnivore and rodent gnawing, root etching, bone weathering stages, etc. (BEHRENSMEYER, 1978; LYMAN, 1994).

Biometric data have been obtained in accordance with the proposals made by DRIESCH (1976). Specific measurements have been applied to some taxa. The methodology followed in the morphometric study of the canids is based on the proposal put forward by ONAR et al. (2005). The osteometric analysis of the birds followed the parameters proposed by COHEN \& SERJEANTSON (1996) and JANSEN \& GESTEL (2015).

The morphometric measurements were taken with a digital calliper using measuring points reported in previous studies. The results are given in $\mathrm{mm}$.

\section{4.- CASUAL OR RITUAL?}

In the case of domestic animals that appear in tombs or structures of a ritual character situated within a funerary area, the association with intentional human activity related to an offering or a funerary event is much clearer than in the case of wild animals. For wild animals, such an interpretation is more likely to apply when they show clear marks of having been sacrificed and dismembered. When they appear whole and in anatomical connection recovered around the perimeter of the pit near the bottom may theoretically originate from animals that fell into the open 
feature by accident prior to burial and were unable to escape from the over $2 \mathrm{~m}$ deep, beehive-shaped pit.

On the other hand, in the case of whole wild animals that are of an infantile or juvenile age, that do not show any marks of sacrifice or use, and that furthermore have a habit of engaging in digging activity or seeking underground refuge, as do badgers and rabbits among others, there is much less reason to attribute their appearance to intentional human activity. For this reason, we have analysed the taphonomic processes associated with the appearance of wild animals. For example frogs and other animals usually escape the cold in underground pits but not at a depth of $2 \mathrm{~m}$.

The presence of remains of reddish adobe in most of the funerary structures indicates that their closure was nonpermanent, facilitating access to them so they could be reused or so offerings could be placed inside. This access seems also to have been used in any moments by certain wild animals who would have gained entrance to the pits in search of protection or food.

\section{5.- RESULTS}

\subsection{Wild animals}

1333 remains of wild species are analysed. Carnivores are represented by two foxes, one large canid (possibly a wolf) and a badger; furthermore, there are various non-identified carnivores, all of them perinatal. Their taphonomic interpretation is diverse and not always self-evident.

As regards wild birds, there are three adult red kites (Milvus milvus), one adult carrion crow (Corvus corone/frugilegus), one juvenile red-legged partridge (Alectoris rufa) and one adult Eurasian coot (Fulica atra). There are also two undetermined remains (CRII459, layer 3A).

Finally, diverse remains of hedgehogs, rabbits, lizards, amphibians and snakes are recorded.

\section{Vulpes vulpes}

The fox is represented by two individuals (Table 5).

The first of these is represented by a single remnant: a right mandible that is complete and well preserved (Figure 3), which was found together with 15 remains from Ovis/Capra and two from Bos taurus inside a silo. This silo is $120 \mathrm{~cm}$ in depth and comprises four distinct layers of filling, all of them with associated ceramic and lithic material, the most notable of which is the fourth, deepest one, which contains four whole vessels that are broken but reconstructible. The fox mandible is from layer 1, the upper layer of structure CRII753, which has been archaeologically classified as a structure that is difficult to interpret due to its location just a few metres away from two funerary structures. This layer was formed in large measure by ash and contained all the above-described faunal remains, none of them burnt except an Ovis/Capra hyoid. However, the lack of other evidence directly linking this structure with the funerary structures prevents us from interpreting this wild remnant as an intentional deposit.

\begin{tabular}{|c|c|c|}
\hline \multicolumn{3}{|l|}{ Vulpes vulpes } \\
\hline & CRII 481 & \\
\hline Scapula Length of glenoid process & 16.5 & \\
\hline Minimum anteroposterior diameter of the scapular neck & 15.4 & \\
\hline Humerus Greatest length & 115 & \\
\hline Mid-shaft diameter & 7.4 & \\
\hline Proximal breadth & 16.8 & \\
\hline Distal breadth & 18.6 & \\
\hline Radius Greatest length & 109.3 & \\
\hline Mid-shaft diameter & 8.4 & \\
\hline Proximal breadth & 10.5 & \\
\hline Distal breadth & 13.8 & \\
\hline Ulna Mid-shaft diameter & 5.1 & \\
\hline Femur Greatest length & 119.4 & \\
\hline Mid-shaft diameter & 8.7 & \\
\hline Distal breadth & 18.8 & \\
\hline Tibia Greatest length & 129.2 & \\
\hline Mid-shaft diameter & 7.7 & \\
\hline Proximal breadth & 19.7 & \\
\hline Distal breadth & 15.2 & \\
\hline Calcaneus Greatest length & 28.7 & \\
\hline Talus Greatest lenght & 16.9 & \\
\hline \multicolumn{3}{|l|}{ Skull } \\
\hline Upper neurocranium length & 64 & \\
\hline Maximum width of neurocranium & 47 & \\
\hline Frontal breadth & 37 & \\
\hline Maximum width of occipital condyles & 24 & \\
\hline Height of the foramen magnum & 11 & \\
\hline Height of the occipital triangle & 28.5 & \\
\hline Greatest breadth of the bases of the jugular process & 35 & \\
\hline Maximum width of the foramen magnum & 15 & \\
\hline Maxilla Length P1-M2 sup. & 52 & \\
\hline Length P4 sup. & 12 & \\
\hline \multirow[t]{2}{*}{ Length canine sup. } & 16 & \\
\hline & CRII481 & CRII753 \\
\hline Mandible Length P1-M3 inf. & 58 & 60 \\
\hline Length M1 inf. & 14 & 16 \\
\hline Length canine inf. & 14.5 & \\
\hline
\end{tabular}

Table 5: Osteometric measurements of Vulpes vulpes

The second individual is from layer 3 of the funerary structure designated CRII481. This is an almost complete individual represented by 130 bony remains (lacking the sacrum, the metatarsals, and most of the phalanges) (Figure 4). It was found for the most part in anatomical connection, although the left anterior extremity was displaced, possibly due to the action of the reptiles and ophidians recorded in the same level, whose presence has been interpreted as intrusive in character. It is apparently from a female individual, given the lack of the penile bone.

The degree of anatomical connection observed, as well as the absence of marks of predation or of the use of animal's skin or flesh, leads us to posit that the deposit was in- 

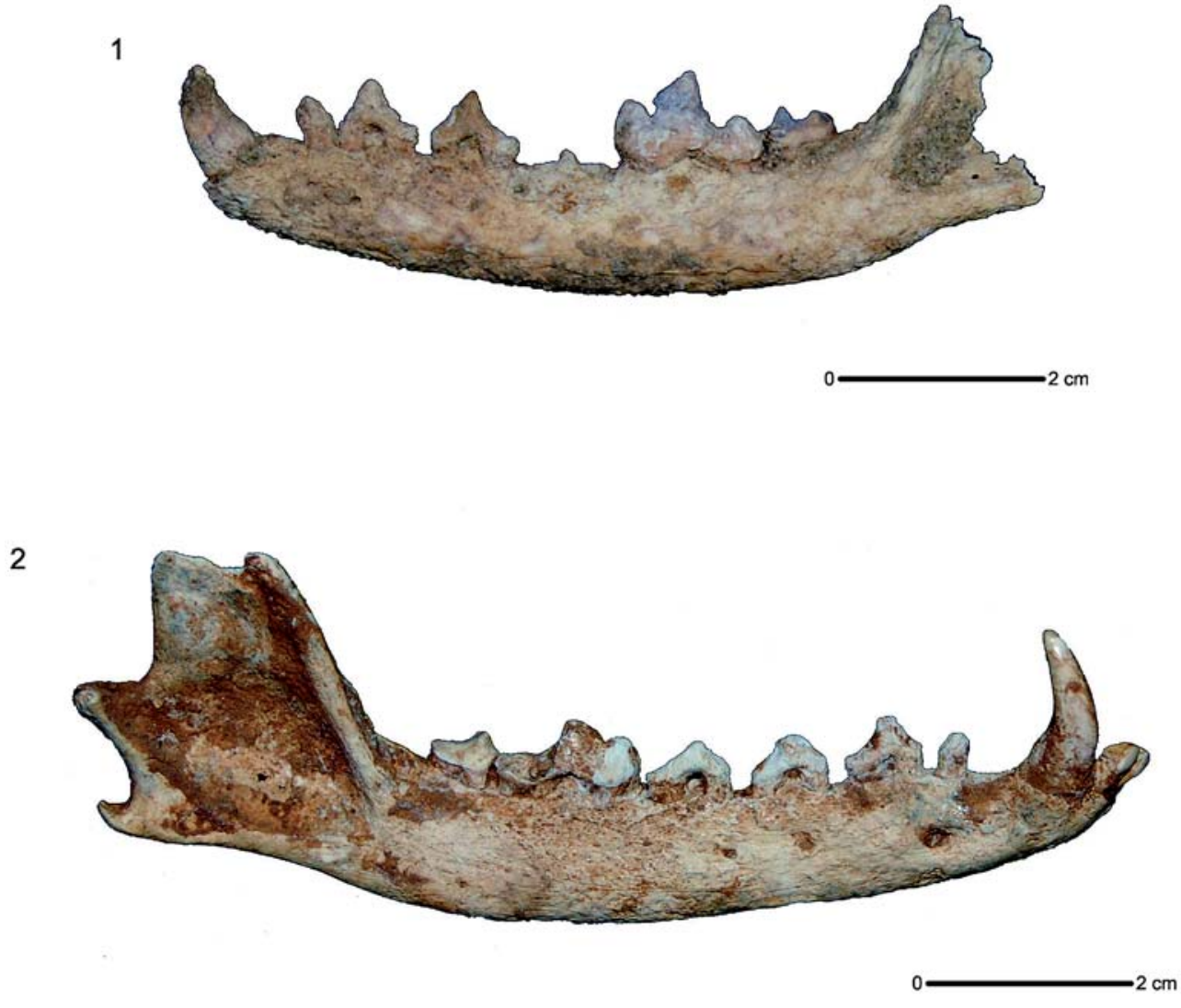

3

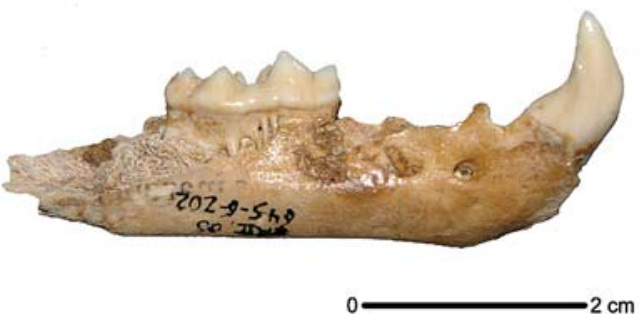

Fig. 3. Carnivore remains. 1: left mandible of Vulpes vulpes (structure CRII-753, level 1); 2 right mandible of Vulpes vulpes (Tomb 481, level 3); 3: right mandible of juvenile Meles meles (Tomb 645, level 6).

tentional, although the clearest indicator of this is the appearance of a perinatal inhumation above the fox. The stratigraphic and archaeological criteria in turn confirm the funerary use of the structure from its bottom to its mouth, where the final interment of a perinatal was carried out, definitively sealing off the pit.

\section{Canis cf. lupus}

Two fragmented bones from the extremities of a large canid were recorded in layer 3 of the multiple hypogeal tomb designated CRII459, together with other intentional deposits, the most remarkable of which, given their proximity, were the humerus and scapula of a medium-sized dog and the bones from one of the legs of a red kite. The bones of the large canid are classified as belonging to a wolf (Canis cf. lupus) on the basis of comparison with the size of various dogs of the site (Table 6). They are the shaft of a right radius and a proximal fragment of the olecranon epiphysis of a right ulna, both of which may belong to the same individual (ALBIZURI, 2011a; MAROTO et al., 2011) (Figure 4).

\section{Meles meles}

The badger is represented by a single individual that is of a juvenile age. It was found in layer 6 of the funerary structure CRII645. It can be presumed that it was originally complete, although as a consequence of the fragility of the 


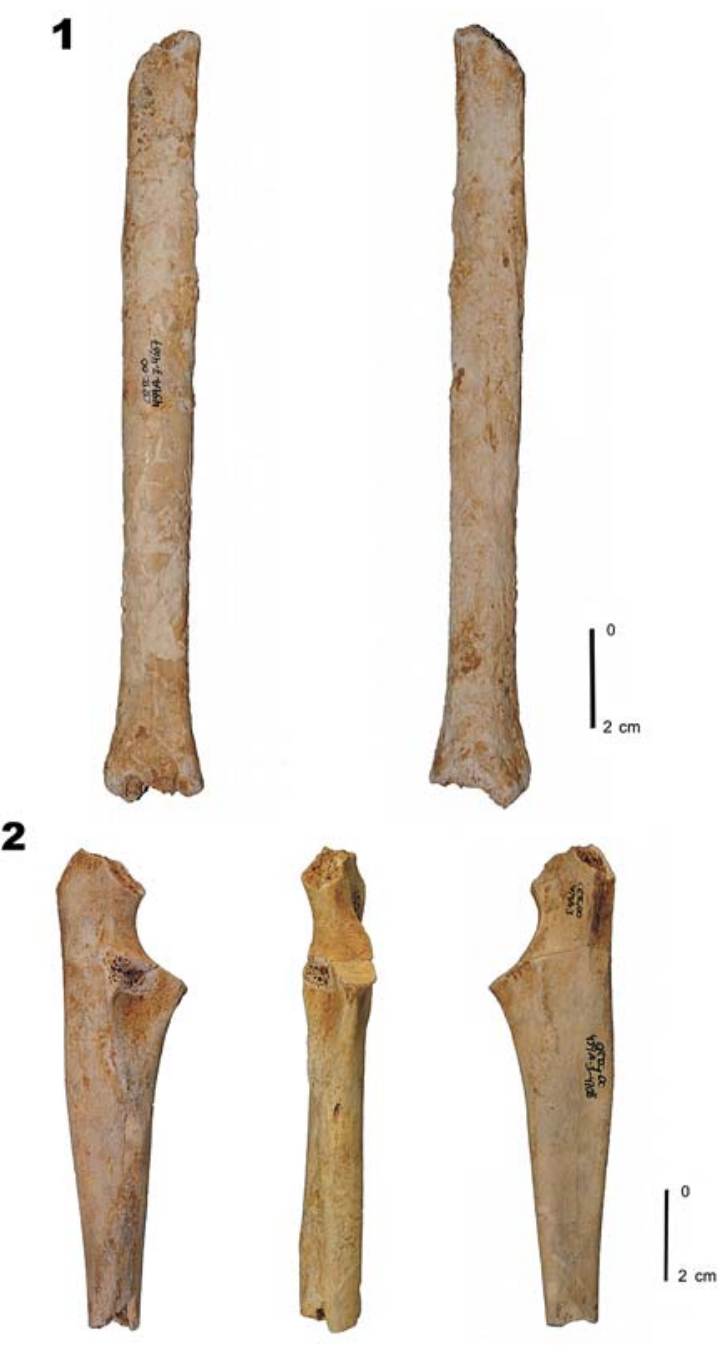

3

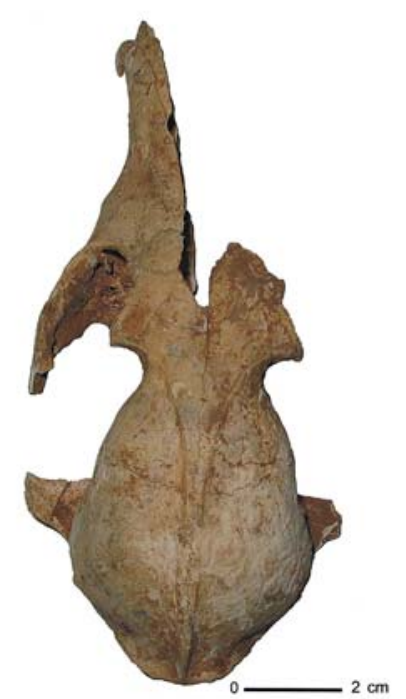

Fig. 4. Carnivore remains. 1 and 2 : right radius and right ulna of Canis cf. lupus (Tomb 459, level 3, chamber A); 3: skull of Vulpes vulpes (Tomb 481, level 3).

\begin{tabular}{|l|c|c|}
\hline & Canis familiaris & Canis cf. lupus \\
\hline Mid-shaft diameter of radius & $11-13(n=6)$ & 15 \\
\hline $\begin{array}{l}\text { Articular shaft diameter of ulna } \\
\text { (taken at medial coronid process) }\end{array}$ & $16-18.6(n=4)$ & 27 \\
\hline Mid-shaft diameter of ulna & $5-7(n=5)$ & 11 \\
\hline Shoulder height (radius) & $47-49.3(n=5)$ & \\
\hline
\end{tabular}

Table 6: Osteometric measurements of Canis cf. lupus in comparison with the Canis familiaris from the site of Can Roqueta II. Estimated shoulder height in cm after Harcourt.

bones it now consists of just 29 remains. Even so, all the parts of the skeleton are present: a complete though fractured cranium, various rib remains, diverse vertebrae, two humeri, two ulnae, one radius, two proximal epiphyses of the femora, a distal epiphysis of a tibia, a calcaneus, metapodials and phalanges (Figure 3). The age has been determined as less than six months, given the absence of dental wear, as well as the general degree of epiphysation (MALLYE, 2007).

While on the one hand the location of this individual within a funerary structure might be taken to imply that its occurrence is of a ritual character, on the other hand the ethology of the badger, the fact that it is a juvenile (infantilejuvenile mortality rates are high among badgers), the absence of other taphonomic or archaeological evidence, as well as the presence of diverse microvertebrate remains that can be interpreted as forming part of its faeces, together lead us to identify its occurrence as intrusive in character or was a possible intruder that died in the nest.

\section{Undetermined Carnivora}

The remains in question are only from perinatal individuals $(\mathrm{NISP}=40)$, detected mainly on the basis of the morphology of certain bones, in particular the scapula. They were found in a single structure (CRII481, layers 3 and 5). They should very probably be considered as naturally occurring.

\section{Corvus corone/frugilegus}

An adult carrion crow was identified in the funerary structure designated CRII481, layer 5 (Figure 5), together with the remains of two red kites and one red-legged partridge as well as a complete sheep in anatomical connection and other partial remains of animals deposited as offerings. The crow is represented by its two legs (two femora and a tibiotarsus) and by the distal extremities of the two wings (two ulnae). It was probably deposited whole, given that in the same assemblage where these bones were collected there were other fragments from the shaft of an undetermined avian bone which seem to correspond to the same specimen, although the lack of diagnostic elements has made it impossible to identify the implied spe- 
1

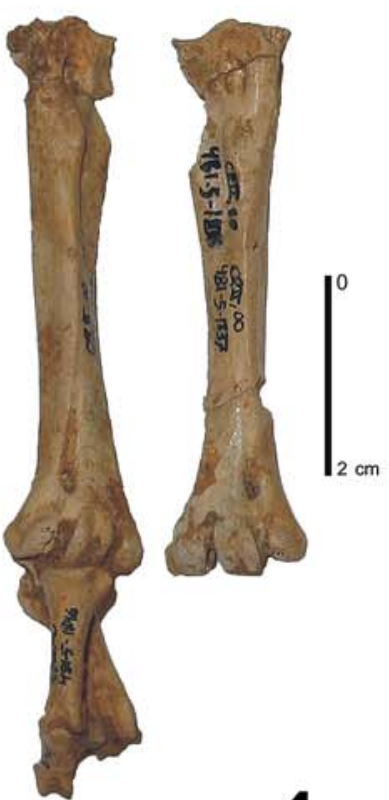

4

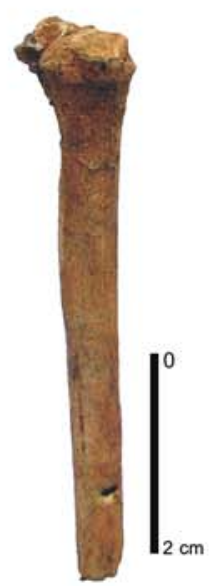

3

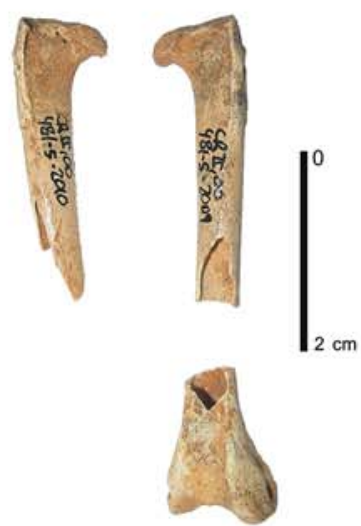

5

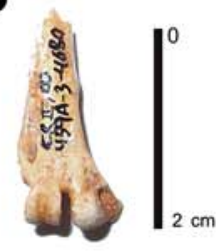

6

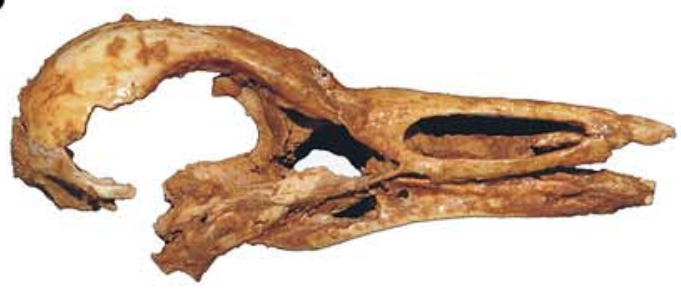

7

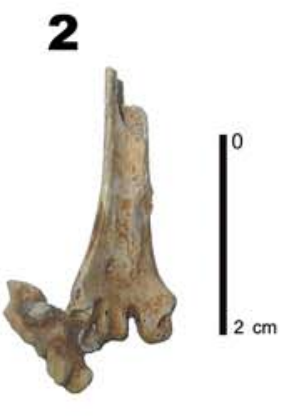


cies with certainty. None of the remains presents signs of predation or anthropic manipulation. As the occurrence of skeletal remains of corvids in Holocene anthropic sites is very scarce - see the compilations by HERNÁNDEZ CARRASQUILLA $(1993,1994)$ - the appearance of a complete, or almost complete, individual is a singular event. However, at the Early Bronze site of Camino de las Yeseras (Madrid), a very similar case has been recorded in the funerary pit of an infant (LIESAU et al., 2008).

\section{Milvus milvus}

The remains of three adult specimens of red kite were recorded in two funerary pits (CR\|481 and CR\|459) (Figure 5). None of them presents marks of predation, previous fractures or cut marks.

Individual I from the pit CRII481 is the best represented. From this specimen the two legs were recovered in anatomical connection, as well as the upper half of the left wing and some parts of the thorax, indicating that it may have been deposited whole. Found together with it was individual II from CRII481, which is only represented by the extremities of the two legs, also in anatomical connection (tarsometatarsals and phalanges), as well as the remains of the afore-mentioned carrion crow, the red-legged partridge and other faunal deposits.

The individual from layer 3 of the funerary structure designated CRII459 was found together with other deposits identified as offerings, among the most notable of which were the above-mentioned remains of the possible wolf. The red kite is represented only by the right leg, which seems to have been deposited whole, although no anatomical connection is observed.

If, as mentioned, the occurrence of a corvid carcass is singular, the finding of skeletal elements from three red kites in anatomical connection is even more unexpected, as the red kite record is notably meagre.

It is noteworthy that in the Early Bronze Age of various sites in Great Britain, remains of bird of prey are frequently found in ritual and funerary spaces (YALDEN, 2002).

\section{Alectoris rufa}

A fragmented juvenile red-legged partridge was documented on the basis of a single remnant found near to the remains of the carrion crow in layer 5 of tomb CRII481. The item in question is a proximal left tibiotarsus without the epiphysis (Figure 5). It does not present marks of predation or anthropic manipulation.

This item is difficult to interpret due to its scarce skeletal representation, but the young age of the animal suggests the possible deficient preservation of the remains and its appearance along with other intentional deposits of birds, implies that this too was an intentional deposit. The red-legged partridge has not previously been recorded in funerary contexts in the Iberian Peninsula.

\section{Fulica atra}

An adult Eurasian coot was documented in layer 2 of the funerary pit CRII583, within a context rich in animal deposits. It is represented by a complete cranium (Table 7) and two phalanges that were found beneath it in clay conglomerate (Figure 5). This finding, which is exceptional given the fragility of the cranium and the grouping of the bones between stone blocks, leads us to conjecture that the remains were possibly wrapped in organic matter for protection, conferring upon them a specific character that corroborates their interpretation as an intentional deposit. This aquatic bird lives in ponds and pools, and nests on the banks. The only other record in the Iberian Bronze is at Cabezo Redondo (DRIESCH \& BOESSNECK, 1969).

\section{Oryctolagus cuniculus}

The common rabbit is represented by 249 remains found in eight structures. The vast majority of these remains are from infantile or juvenile individuals, and the few from adults are isolated. The ethology of the rabbit and the lack of archaeological criteria lead us to believe that the presence of these remains is intrusive or casual.

\section{Erinaceus europaeus}

In layer 5 of the structure CRII481 thirteen remains from a complete hedgehog were found. There are no taphonomic or archaeological criteria available for interpreting its presence so they have been cautiously classified as casual.

\section{Lacerta sp.}

Numerous lizard remains $(n=270)$ were found, isolated or in anatomical connection. These correspond to a minimum of eight individuals, which were discovered of bottom in six structures (only in funerary structures). Are represented by well-preserved skeletons in one structure (Tomb 481, level 4, 5, and 6). In the absence of archaeological evidence, they are classified as casual. Their presence may have various explanations: they may have fallen in or infiltrated in the structure from outside, or they may have been brought in by other animals, etc.

\begin{tabular}{|l|l|}
\hline Fulica atra & \\
Cranium & \\
\hline Total length & 67 \\
\hline Length (cranium) & 32 \\
\hline Width (cranium) & 20 \\
\hline Height (cranium) & 24 \\
\hline Length (bill) & 34 \\
\hline Skull ratio (Total length / length bill) & 1.97 \\
\hline
\end{tabular}

Table 7: Osteometric measurements of Fulica atra. 
In any case, in the absence a taxonomic study, a definitive explanation for their presence is left open.

\section{Serpentes}

The snake remains are the best represented (no. of vertebras $=519$ ), and they were all found in anatomical connection. They represent seven individuals headless, which were discovered of bottom in five structures (two in ritual structures and three in funerary structures). Are represented by well-preserved skeletons in one structure (Tomb 481, level 4, 5, and 8). They are interpreted as possible intruders since it is common for ophidians - above all terrestrial ones - to seek refuge in burrows or pits. Their occurrence in anatomical connection probably reflects the fact that they died there. In any case, in the absence of skulls and a taxonomic study, a definitive explanation for their presence is left open. Importantly, however, that some snake species are not able to dig themselves; they tend to occupy burrows left behind by other animals.

\section{Anura}

Anuran amphibian remains were found isolated and not in anatomical connection. They were present in seven structures and indicate a minimum of seven individuals. They are classified as casual because they could have come from the outside (having fallen in or infiltrated the structure) or been brought in by other animals, or they could be intrusive given their behaviour.

\subsection{Intentional wild animal deposits in a funerary context}

Only some wild carnivores and wild birds are considered intentional deposits. 174 remains appear in three out of 47 funerary structures and constitute $5.9 \%$ of the NISP and $3.1 \%$ of the $\mathrm{MNI}$, whereas $94.1 \%$ of the NISP and $96.9 \%$ of the MNI represent domestic species (Table 2).

Four species of birds (Milvus milvus, Corvus corone/frugilegus, Alectoris rufa, Fulica atra) and two species of carnivores (Vulpes vulpes, Canis cf. lupus) have been interpreted as offerings, amounting to a total of eight individuals (Table 8 ). The most frequently recorded skeletal parts are isolated bones: bones of the extremities, sometimes articulated; also bones from the trunk and cranium. Marks of human manipulation (alterations caused by fire and cut marks) are nonexistent.

We are led to interpret them as funerary offerings not only in the light of their archaeological and stratigraphical context but also their skeletal representation following the pars pro toto principle (particularly noteworthy is the remarkable record of a coot cranium and two possibly complete red kite and carrion crow specimens), as well as the state of preservation of the bones, the partial anatomical connections and the absence of any taphonomic indicators suggesting the contrary. Also, birds and foxes are represented during the Neolithic and Bronze Age in the Iberian Peninsula (MARTÍ et al., 1997; LIESAU et al., 2008), and the wolf during the Mesolithic and Neolithic in Europe (BERNABÒ BREA et al., 2010; BARTOSIEWICZ et al., 2013; GRUNBERG, 2013).

Finally hedgehogs, rabbits, lizards, amphibians, snakes and various non-identified carnivores that are recorded, all of them perinatal, are included among the intrusive animals because some are represented by well-preserved skeletons found in more-or-less anatomical order indicative of potentially in situ death and other are represented by isolated remains, and also because there are no taphonomic indicators or cut marks suggesting the contrary. On the other hand, these species can currently also be found in the region and their potentially natural origins in the burials are possible. However, the hypothesis cannot be ruled out that some of these remains were intentionally introduced into the structures, as there are examples of the use of badgers, snakes and amphibians and reptiles in Mesolithic and Neolithic burials in Europe, where they are interpreted as amulets or items with special ritual or symbolic meaning (BERNABÒ BREA et al., 2010; BARTOSIEWICZ et al., 2013; GRUNBERG, 2013) and perhaps it's not casual the apparition of well-preserved skeletons of one hedgehog, three snakes and three lizards in one structure of Can Roqueta II (Tomb 481, level 4, 5, 6 and 8 were have been found human remains).

\begin{tabular}{|l|c|c|c|c|c|}
\hline & Tomb & Level & NISP & Description & Individual \\
\hline Milvus milvus (red kite) & 459 & 3 & 4 & Isolated bones: femur, tibiotarsus, fibula, tarsometatarsus & adult \\
\hline Canis cf. lupus (wolf) & 459 & 3 & 2 & Radius, ulna & adult \\
\hline Vulpes vulpes (fox) & 481 & 3 & 130 & Complete & female adult \\
\hline Milvus milvus I (red kite) & 481 & 5 & 22 & Partial: humerus, furcula, femur, tibiotarsus, tarsometatarsus-phalanges & adult \\
\hline Milvus milvus II (red kite) & 481 & 5 & 7 & Isolated bones: tarsometatarsus-phalanges & adult \\
\hline Corvus corone/frugilegus (carrion crow) & 481 & 5 & 5 & Isolated bones: femur, tibiotarsus, radius & adult \\
\hline Alectoris rufa (red-legged partridge) & 481 & 5 & 1 & Isolated bones: tibia & juvenile \\
\hline Fulica atra (eurasian coot) & 583 & 2 & 3 & Isolated bones: skull, 2 phalanges & adult \\
\hline
\end{tabular}

Table 8: Wild carnivores and wild birds in funerary structures. 
Tomb 459

This is a hypogeum comprising a central pit $(A)$ with a depth of $2.5 \mathrm{~m}$ and three lateral chambers (B-C-D) from which 24 individual human skeletons have been documented (10 adults and 14 infants) and a number of isolated bones, from various funerary levels (Figures 6, 7). Dated by radiocarbon to between 1932-1630 cal BC (3465 \pm 60 BP UBAR-697), it has provided a total of 384 faunal remains, which include intentional deposits: one complete animal ( 1 pig in chamber $\mathrm{C}$ ), two partial animals ( 1 goat and 1 pig in chamber A) and 20 animals represented by isolated bones ( 4 cows, 1 sheep, 1 pig, 1 dog, 1 wolf and 1 red kite in chamber $A ; 2$ cows, 1 sheep, 2 goats and 2 pigs in chamber $\mathrm{C}$; 1 cow, 1 indeterminate ovicaprine and 2 pigs in chamber D). The absence of gnawed bones and post-depositional surface modifications caused by water, humidity or heat suggests that the structure remained covered throughout the period of activity and was only opened to add a new deposit.
Associated with the isolated human remains in level 3 of Chamber A, intentional deposits include two bones from the left forearm of the adult large canid (possibly a wolf) (Figure 4), as well as four bones from the right leg of an adult red kite (Figure 5), which were deposited jointly with other domestic faunal remains.

Tomb 481

Dated by radiocarbon to $1940-1734 \mathrm{cal}$ BC $(3500 \pm 45$ BP UBAR-797), this simple silo-type pit, conserved in its totality, with a depth of $2.2 \mathrm{~m}$ contained the remains of eight complete human individuals: one in level 1 and seven in level 6, as well as an isolated fibula in level 8 (Figure 8) and an adult cranium without a mandible in level 5 (Figure 9).

1551 faunal bony remains have been identified, which include intentional deposits: five complete animals in anatomical connection (2 dogs, 1 sheep - Figure 10 -, 1 pig, 1 fox); two partial animals (1 sheep, 1 red kite) and six ani-

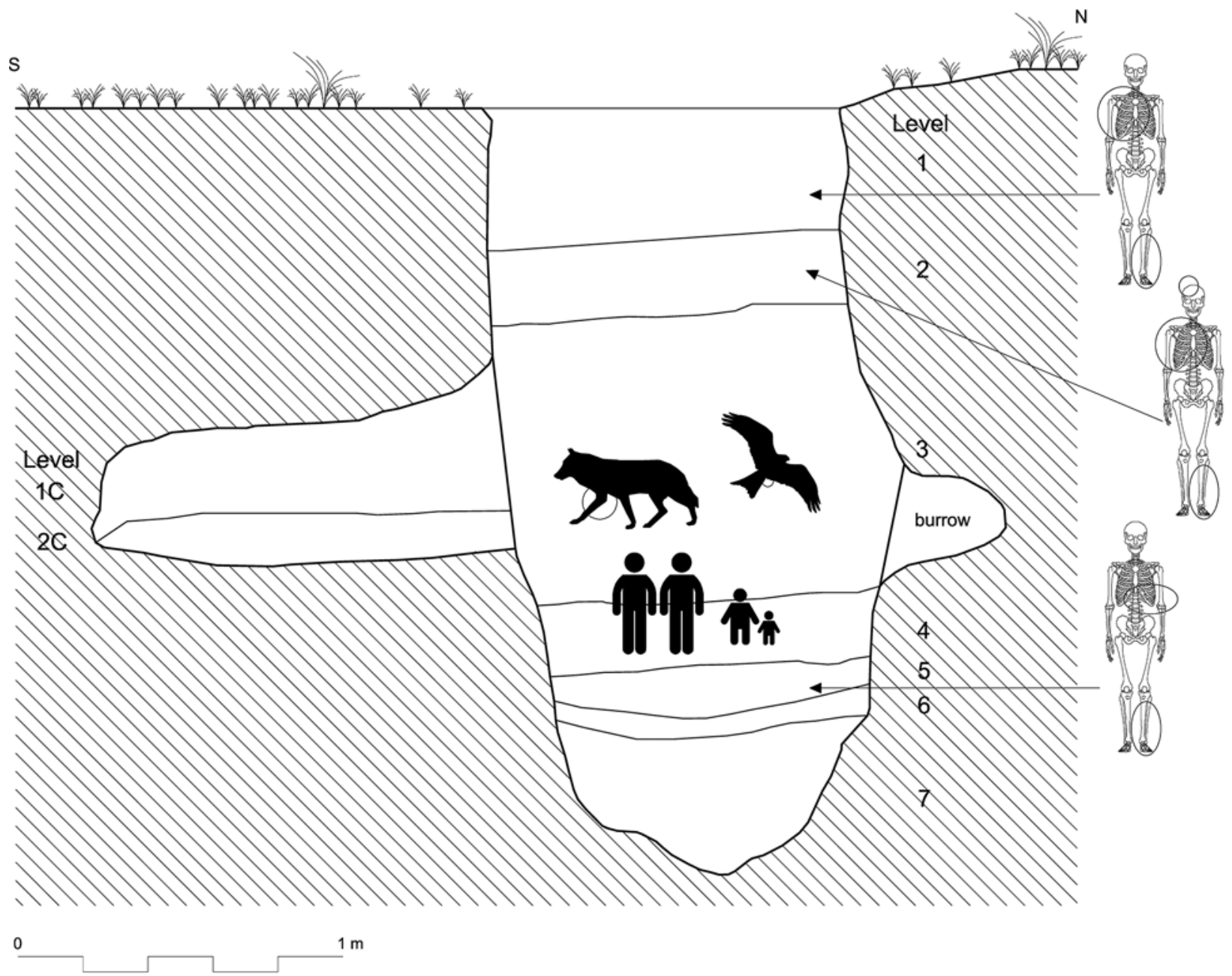

Fig. 6. Section of Tomb 459. Wild carnivores, wild birds and human deposits in the central pit (A) 

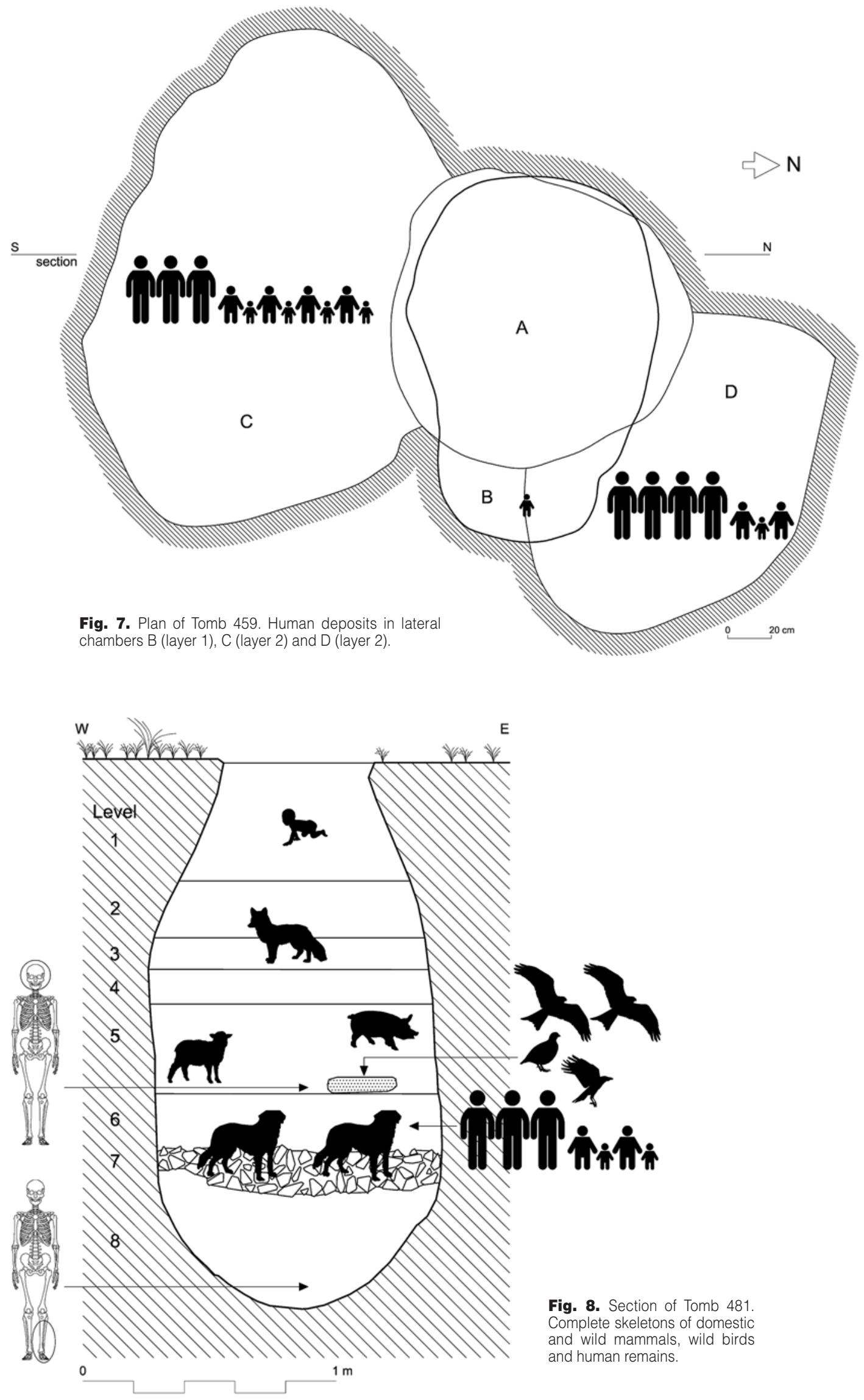

Fig. 8. Section of Tomb 481 Complete skeletons of domestic and wild mammals, wild birds and human remains. 


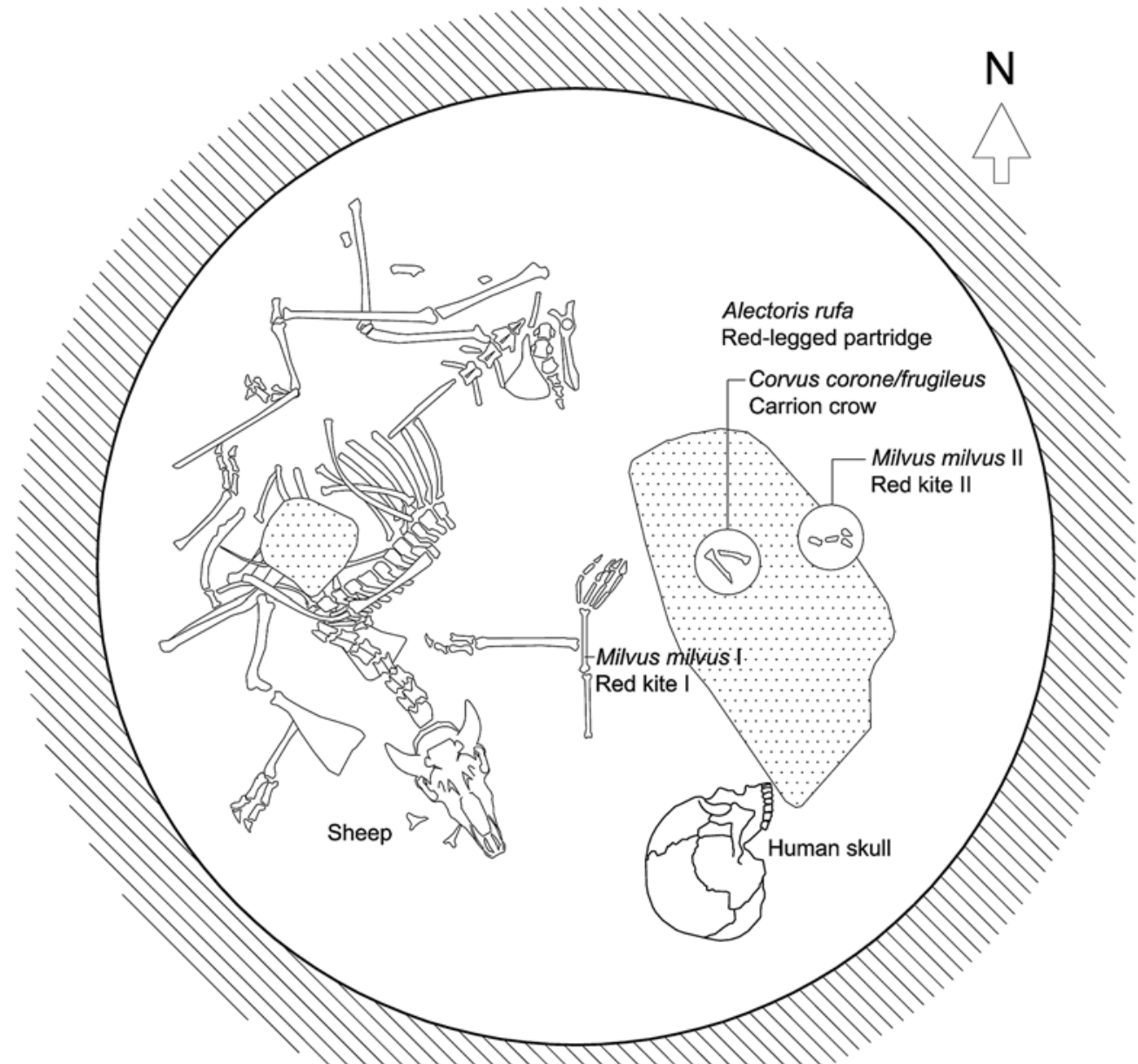

0 $20 \mathrm{~cm}$

Fig. 9. Plan of level 5 of Tomb 481. Wild birds, complete sheep and human skull remains.

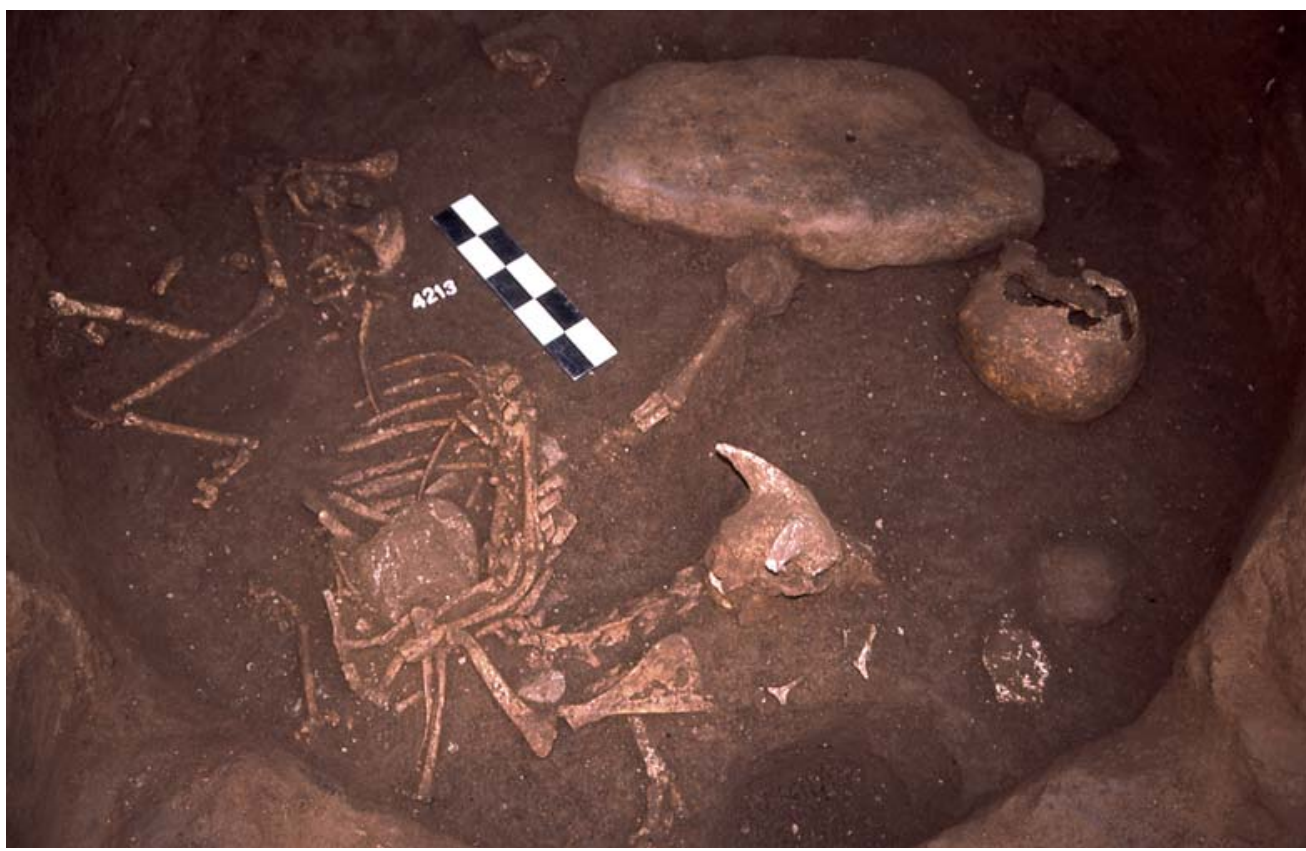

Fig. 10. Complete sheep and human skull remains of level 5 of Tomb 481. 
mals represented by isolated bones ( 1 cow, 1 sheep, 1 domestic goat, 1 red kite, 1 carrion crow, 1 red-legged partridge). The absence of gnawed bones and post-depositional surface modifications due to water, humidity or heat indicates that the structure must have remained covered during the period of activity and would have only been opened in order to carry out a new burial or animal deposit.

In level 5, together with the isolated human cranium and the articulated skeleton of a sheep (Figure 10) with cut marks in the atlas indicating that its throat was cut, and beneath the articulated skeleton of a pig, bones were found belonging to four wild birds (Figure 8): two adult red kites (Milvus milvus), one adult carrion crow (Corvus corone/frugilegus) and one juvenile red-legged partridge (Alectoris rufa).

The first red kite was found next to a large stone that was covering a large part of the human skeletons. It is the most complete specimen and had maintained the tarsometatarsi and the corresponding bones of the feet in anatomical connection (Figures 5, 9).
The other red kite is represented by one fragmentary left tarsometatarsus (Figures 5, 9). It was found on top of the large stone, together with the remains of a red-legged partridge (fragmentary left tibiotarsus) (Figures 5, 9), and those of a carrion crow (fragmentary ulnae, femora and a partial tibiotarsus) (Figures 5, 9).

The articulated skeleton of an adult female fox was recorded in level 3 (Figure 11), lying on its left side and oriented from west (head) to east. It presented only certain skeletal parts out of anatomical position, probably due to the activity of the intrusive animals (snakes, lacertids and small mammals) detected within this level. Above this animal the last burial - of a perinatal individual - was carried out (level 2).

\section{Pit 583}

This is a simple silo-type structure with a depth of $1.7 \mathrm{~m}$, in which structured faunal deposits have been identified and one human remnant that gives it its funerary character.

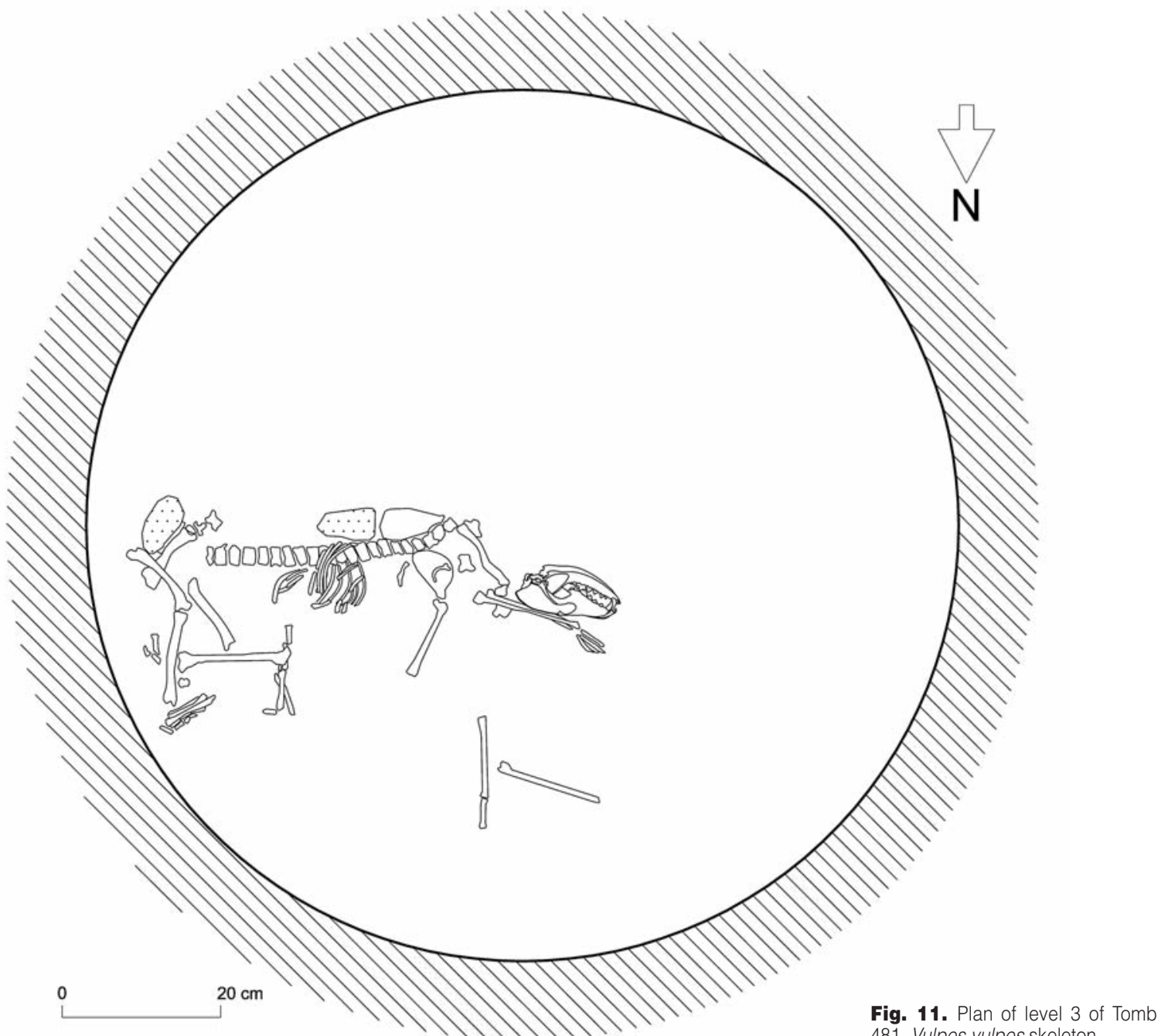

481. Vulpes vulpes skeleton. 
It has not been dated by radiocarbon, although it can be situated in the first half of the second millennium $\mathrm{BC}$ on the basis of the material found inside it. At the centre of level 3 , a fragment of an adult human cranium was deposited beneath a large stone, next to the anterior right end in anatomical connection of a dog and the articulated skeleton of a piglet; the fragment of human cranium is a calvaria that preserves a good part of the frontal and part of the two parietals, and belongs to an adult individual of indeterminate sex. In level 2, other faunal deposits are laid out along the northwestern and eastern walls. In the centre the cranium of a dog stands out, separated by incisions in its occipital condyles; likewise, there is a well-preserved sacrum from a small adult cow. Above this, in the centre of level 1 there is a cow cranium and other remains.

In total, 445 faunal remains have been recorded; most of those in level 2 have been interpreted as intentional deposits: five complete and articulated animals (4 piglets and $1 \mathrm{dog}$ ) and 14 animals represented by isolated bones (2 cows, 3 sheep, 1 goat, 2 ovicaprines, 1 pig, 4 dogs and 1 coot) (Figure 12).
The cranium and two digit phalanges of the Eurasian coot (Fulica atra) (Figure 5) were found between mediumsized stones that covered the offerings of layer 2 (Figure 13).

\section{6.- DISCUSSION: DEPOSITS IN A FUNERARY CONTEXT}

The best-represented species are the domestic ones, both in the funerary pits and in the additional installations interpreted as ritual in character. These are also the species raised for consumption and milk production. This same tendency comes to light in many parts of the world in the second millennium BC (HAMILAKIS, 1998; JEUNESSE, 2001; KANSA \& CAMPBELL, 2004; JING \& FLAD, 2005; REINOLD, 2005; SCHWARTZ, 2007). These offerings are associated with the provision of food and with the economic importance of the animal and possibly with a demonstration of social status, especially in cases of whole animals that have not been consumed, such as the complete sheep that was slaughtered and deposited in Tomb 481. Nonetheless, their totemic significance - as protection and

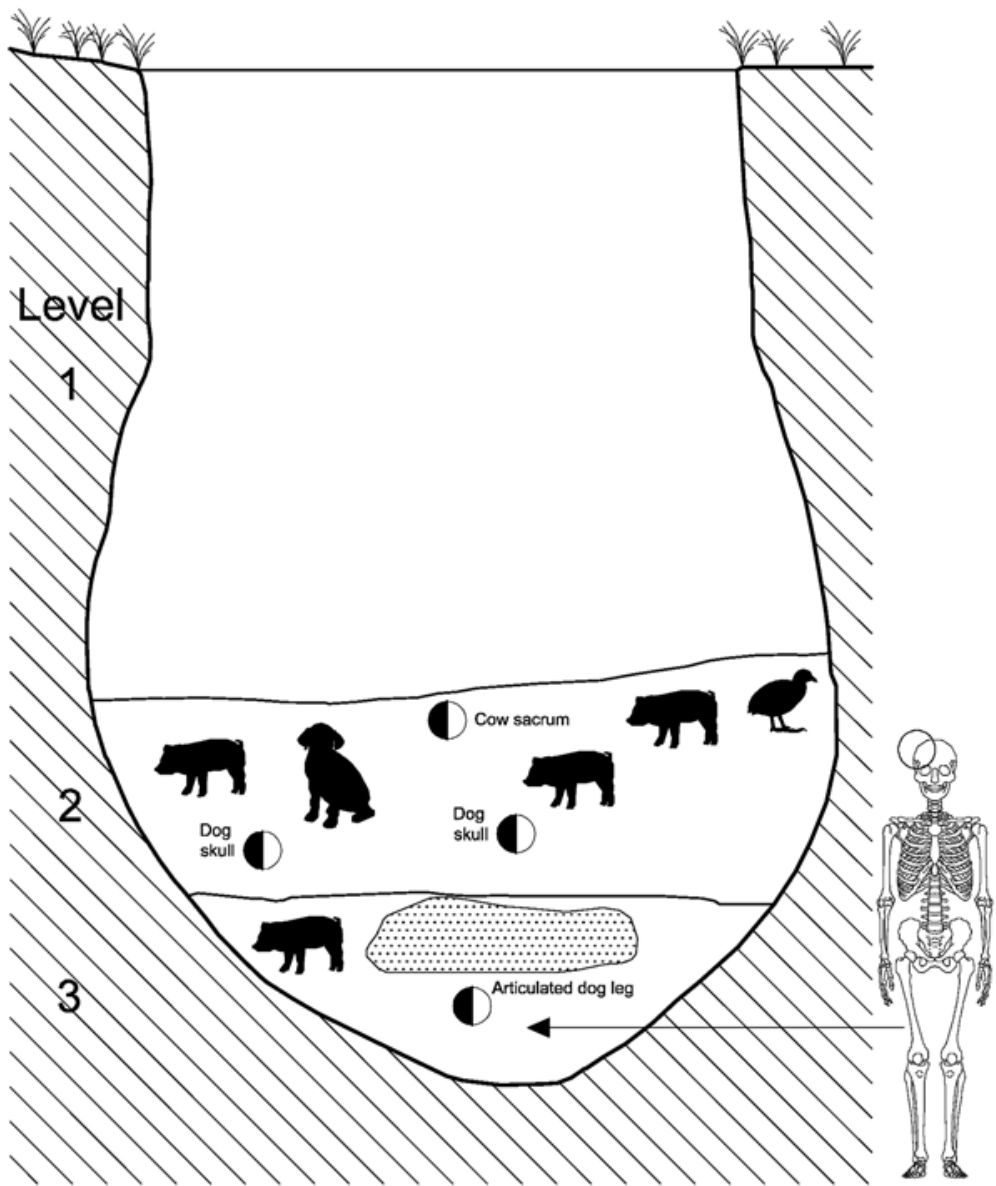

0
Fig. 12. Section of Pit 583. Wild bird (Fulica atra), complete piglets, cow, dog and human remains. 


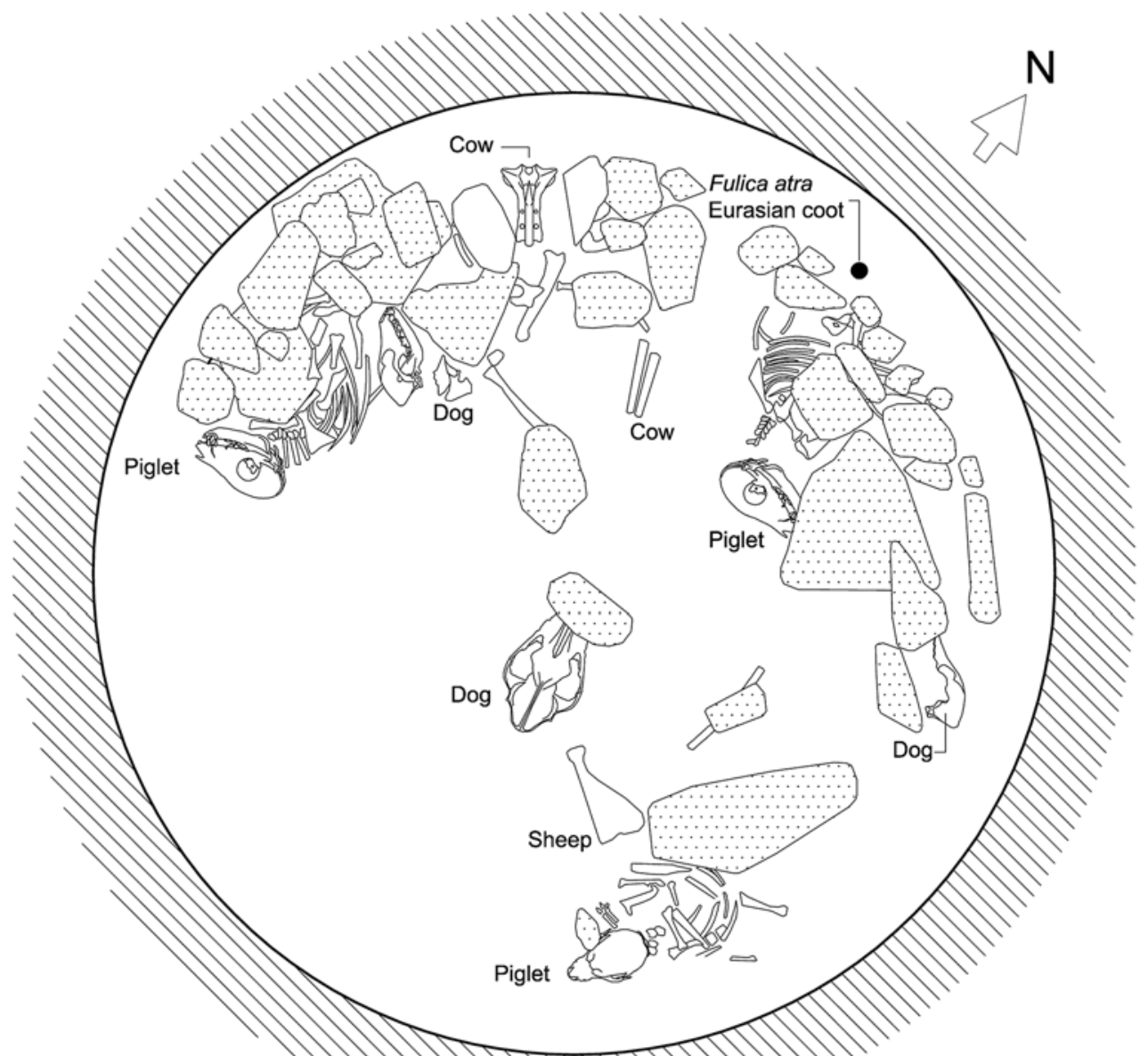

0 $20 \mathrm{~cm}$

purification - cannot be ruled out either (DAVIS \& PAYNE, 1993; COLLINS, 2002, 2006; HELMER et al., 2004; RUSSELL, 2012). By contrast, the wild species identified are not associated with daily human consumption, and among the birds the anatomical parts represented are poor in meat. From the characteristics of the bones (no cut marks, no signs of cremation, etc.) and their arrangement in the structures, the six wild species have been interpreted as intentional deposits not related with food offerings.

The assemblage of these six species (Milvus milvus, Corvus corone/frugilegus, Alectoris rufa, Fulica atra, Vulpes vulpes and Canis cf. lupus) is of little palaeoenvironmental significance. The species can currently also be found in the region (the red kite more sporadically so, only during migration), and would have been common in the Bronze Age. They indicate an environment with open spaces, aquatic areas with vegetation and woodland. However, their archaeological significance within the assemblage of the site is remarkable. Normally they are not used for human consumption, but they are certainly hunted to be exploited for their fur, feathers and ritual use.
Fig. 13. Plan of level 2 of Pit 583 . Animal remains.
The placement of canids inside human tombs, especially the dogs, is very frequent over the course of history in widespread areas (MOREY, 2010; ALBIZURI et al., 2011). Dogs became symbols of protection and guides of souls in the Hittite society of the second millennium BC (COLLINS, 1990). Among the distinct species of canids, deposits of wolves and foxes were less common, these being more closely associated with totemic images (BRÜCK, 1999). Among the indigenous populations of America, the wolf has been considered an animal with notable spiritual qualities, giving rise to a special relationship with the warrior due to its strategic behaviour (MOREY, 2010). In Mexico dogs, coyotes and hybrids were deposited in ritual areas, symbolizing entrance to the underworld, rebirth and hence fertility (RUSSELL, 2010).

The fox is much more frequent in Eurasian sites from the Neolithic on (HORWITZ \& GORING-MORRIS, 2004; MAHER et al., 2011), but it is scarcely represented in the Iberian Peninsula. Another case is from the Middle Neolithic, recorded in Camí de Can Grau in Catalonia (MARTí et al., 1997). 
Birds are scarcely represented during the Bronze Age in Europe (YALDEN, 2002; MANNERMAA, 2008; MORRIS, 2011). Diurnal birds of prey are associated with protection in Pre-Pottery Neolithic petroglyphs in the Near East (HELMER et al., 2004; MAHER et al., 2011). Other types of wild birds, such as corvids, aquatic birds and owls, pigeons and partridges, are interpreted as being more closely associated with the souls of the deceased and with death. This is on account of their nocturnal, scavenging habits, their black colour and the fact that from the Neolithic to the second Iron Age in Europe they formed part of offerings and funerary images (LIESAU et al., 2008; MANNERMAA, 2008; RUSSELL, 2010; SERJEANTSON \& MORRIS, 2011).

In the European Neolithic, the appearance of wild animals in tombs is interpreted as the opposite case to that of domestic animals and food offerings, since their value in the economy is lower because hunted animals provide only a sporadic meat contribution. Therefore, their symbolic value must be interpreted within a religious dimension (ARBOGAST, 2013)

The appearance of wild species should thus be questioned within this context dominated by animals that were important for the economy, and it should be borne in mind that among the peoples of Siberia the sacrifice of wild animals is currently carried out in funerals in order to achieve rebirth (HAMAYON, 2001). On the other hand, some of the avian species found, such as the partridge and the coot, would have been of use as a food resource for humans. The other species require complex culinary processes to make them acceptable for human taste.

\section{7.- CONCLUSION}

The remains of six individuals of wild birds and one complete fox and one wolf represented by two arm bones are exceedingly rare funerary offerings in contrast with the intentional deposits of domestic animals.

In the agro-pastoral community of Can Roqueta II, repeated findings of domestic animal in funerary structures provide evidence of ritual behaviour in the face of death. These deposits are certainly linked to distinct symbolisms and purposes. In the case of domestic animals, deposits of the skeletal elements richest in meat, in anatomical connection, and with cut marks, suggest offerings of meat quarters as food. Among these, normally there is no sign of the identity of the animal (no skull, no extremities, no teeth, etc.), and the dominant species are those that are consumed as part of the daily diet (cattle, ovicaprids and pigs).

To judge by the offerings recorded, the importance of the domestic stock of animals was much greater than that of wild animals, and their significance in human nutrition and in production may possibly have reflected the power and status of the deceased, above all in certain tombs where there was a large volume of whole animals that had not had their flesh removed or been cooked and had thus not been consumed during the funeral service. Thus, the findings of complete skeletons of unconsumed domestic animals could be a reflection of displays of power given the great importance of their role in the economy. Furthermore, the meaning of the dog sacrifices - in the light of the fact that the dogs were deposited in a complete state and did not form part of the day-to-day nutrition - was surely related to the function of accompanying the deceased, who was probably his master and partner. The observed patterns thus suggest ritual behaviour and provide clear evidence of a belief in life after death.

Finally, the very scarce presence of intentional deposits of wild animals in three tombs suggests a degree of variability in the community by comparison with more frequent ritual habits. Birds and carnivores are not normally associated with human alimentation and food offerings. In this case there are no cut marks, and the remains are clearly associated with the identificatory anatomical parts. The possibility of their totemic and symbolic significance cannot be ruled out.

\section{8.- ACKNOWLEDGEMENTS}

The excavations of Can Roqueta II were financed by the Junta de Compensación of Can Roqueta II and carried out under the coordination of the Museu d'Història de Sabadell. This paper has been supported by the Departament d'Història i Història de l'Art de la Universitat de Girona and by ministerial project HAR2010-22013. Rupert Glasgow translated the text into English. The restoration of the coot cranium was carried out by Isaac Rufí.

\section{9.- REFERENCES}

ALBIZURI, S

2011a Animales sacrificados para el cortejo fúnebre durante e bronce inicial (2300-1300 cal BC). El asentamiento de Can Roqueta II (Sabadell, Barcelona). Quaderns de Prehistòria i Arqueologia de Castelló 29, 7-26.

2011b Depósitos de ovicaprinos en ámbito doméstico ibérico. El ejemplo del poblado de Ca n'Oliver (Cerdanyola de Vallès, Barcelona). Archaeofauna 20, 85-101.

ALBIZURI, S., FERNÁNDEZ, M. \& TOMÁS, X.

2011 Evidencias sobre el uso del perro en la carga durante e Bronce Inicial en la Península Ibérica: el caso de Can Roqueta II (Sabadell, Barcelona). Archaeofauna 20, 139-155.

ALBIZURI, S., SUBIRÀ, M.E. \& RUIZ, J.

2015 Ritual Patterns in the Deposits of Fauna Associated with Iberian Burials: The Necropolis of El Poblado During the Fourth to Second Centuries BC (Archaeological Complex of Coimbra del Barranco Ancho, Murcia). International Journal of Osteoarchaeology 25 (2), 188-200.

ARANDA, G. \& ESQUIVEL, J.A.

2007 Poder y prestigio en las sociedades de la cultura de El Argar. El consumo comunal de bóvidos y ovicapridos en los rituales de enterramiento. Trabajos de Prehistoria 64 (2), 95-118 
ARBOGAST, R.M.

2013 Food offerings in graves from the Danubian Neolithic (5500-4900 B.C.) in the upper Rhine valley. Anthropozoologica 48 (2), 255-261.

\section{BARTOSIEWICZ, L., KOVÁCS, Z.E. \& FARKAS, B.}

2013 Pass the Skeleton Key... Animals in an Early Copper Age inhumation burial from Pusztataskony-Ledence I, Hungary, in STARNINI, E. (Ed.). Uncorformist Archaeology. Papers in honour of Paolo Biagi. 77-88. BAR International Series 2528.

\section{BEHRENSMEYER, A.K.}

1978 Taphonomic and ecologic information from bone weathering. Paleobiology 4, 150-162.

\section{BERNABÒ BREA, M., MAZZIERI, P. \& MICHELI, R.}

2010 People, dogs and wild game: evidence of human-animal relations from Middle Neolithic burials and personal ornaments in northern Italy. Documenta Praehistorica 37, 125145.

BLASCO, M.C., BLANCO, J.F., LIESAU, C., CARRIÓN, E., GARCÍA, J., BAENA, J., QUERO, S. \& RODRÍGUEZ, M.J.

2007 El Bronce Medio y Final en la región de Madrid. El poblado de la Fábrica de Ladrillos (Getafe, Madrid). Estudios de Prehistoria y Arqueología Madrileñas 14-15, 7-372.

\section{BLASCO, M.C., LIESAU, C. \& RÍOS, P. (Eds.)}

2011 Yacimientos calcolíticos con campaniforme de la región de Madrid: nuevos estudios. Patrimonio Arqueológico de Madrid 6. Universidad Autónoma de Madrid. Madrid.

\section{BLUMENSCHINE, R.J., MAREAN, C.W. \& CAPALDO, S.D.}

1996 Blind tests of interanalyst correspondence and accuracy in the identification of cut marks, percussion marks, and carnivore tooth marks on bone surfaces. Journal of Archaeological Science 23, 493-507.

BRADLEY, R.

2005 Ritual and domestic life in Prehistoric Europe. Routledge. London.

BRÜCK, J.

1999 Ritual and Rationality: Some Problems of Interpretation in European Archaeology. European Journal of Archaeology 2 (3), 313-314

CÁMARA SERRANO, J.A., LIZCANO PRESTEL, R., PÉREZ, C. \& GOMEZ DEL TORO, E.

2008 Apropiación, sacrificio de los animales en el Polideportivo de Martos. Sus implicaciones en los orígenes de la desigualdad social. Cuadernos de Prehistoria de la Universidad de Granada 18, 55-90.

CÁMARA SERRANO, J.A., SPANEDDA, L., GÓMEZ DEL TORO, E. \& LIZCANO PRESTEL, R.

2010 La discusión sobre la función de los fosos en la Prehistoria Reciente del sur de la Península lbérica, en ABELLAN PÉREZ, J., LAZARICH GONZÁLEZ, C. \& CASTAÑEDA FERNÁNDEZ, V. (Eds.). Homenaje al Profesor Antonio Caro Bellido. I Prehistoria y Protohistoria de Andalucía y Levante. 61-80. Servicio de publicaciones, Universidad de Cádiz. Cádiz.
CARLÚS, X., LÓPEZ CACHERO, F.J., TERRATS, N., OLIVA, M. PALOMO, A. \& RODRÍGUEZ, A.

2008 Diacronia durant la prehistòria recent a Can Roqueta (Sabadell-Barberà del Vallès, Vallès Occidental) entre el VI I el I mil·lenni cal ANE. Cypsela 17, 115-142.

CASTAÑOS, P. M.

1994 Estudio de la fauna de la necrópolis de Villaricos (Almería). Archaeofauna 3, 1-12.

CLUNLIFFE, B.W.

1993 Fertility, propitiation and the gods in the British Iron Age. Stichting Nederlands Museum voor Anthropologie en Praehistorie. Amsterdam.

CODINA, F., MARTÍN, A., NADAL, J., DE PRADO, G. \& VALENZUELA, S.

2009 Étude et interprétation des dépôts fauniques sous pavement identifiés au Puig de Sant Andreu (Ullastret, Catalogne), in BONNARDIN, S., HAMON, C., LAUWERS, M. \& QUILLIEC, B. (Dirs.) Du matériel au spirituel. Réalités archéologiques et historiques des "dépôts " de la Préhistoire à nos jours. 137-144. XXIXe Rencontres Internationales d'Archéologie et d'Histoire d'Antibes. APDCA Antibes.

COHEN, A. \& SERJEANTSON, D.

1996 Manual for the Identification of Bird Bones from Archaeological Sites. Archetype Publications. London.

COLLINS, B.J.

1990 The puppy in Hittite ritual. Journal of Cuneiform Studies 42 (2), 211-226.

2002 Necromancy, fertility and the dark earth: the use of ritua pits in Hittite cult, in MIRECKI, P.A. \& MEYER, M.W. (Eds.) Magic and ritual in the ancient world. 224-241. Brill, Leiden. Boston and Köln.

2006 Pigs at the gate: Hittite pig sacrifice in its eastern Mediterranean context. Journal of Ancient Near Eastern Religions 6 (1), 155-188.

DAVIS, S.

2008 "Thou shalt take of the ram... the right thigh; for it is a ram of consecration..." some zoo-archaeological examples of body-part preferences, in D'ANDRIA, F., DE GROSSI, J. \& FIORENTINO, G. (Eds.). Uomini, piante e animali nella dimensione del sacro. 63-70. Edipuglia. Bari.

DAVIS, S. \& PAYNE, S.

1993 A barrow full of cattle skulls. Antiquity 67, 12-22.

DRIESCH, A. von den

1976 A guide to the measurement of animal bones from archaeological sites. Peabody museum bulletin 1. Harvard university press.

DRIESCH, A. von den \& BOESSNECK, J.

1969 Die fauna des «Cabezo Redondo» bei Villena (Prov. Alicante). Studien über frühe Tierknochenfunde von der Iberischen Halbinsel 1, 43-95. 
D'IATCHENKO, V. \& DAVID, F.

2010 Usages ordinaires et rituels de la viande dans le basin de I'lénisseî: l'exemple du renne et du mouton. Anthropozoologica 45 (1), 11-23.

Equip Minferri

1997 Noves dades per a la caracterització dels assentaments a l'aire lliure durant la primera meitat del II mil.lenni cal. $\mathrm{BC}$ : primers resultats de les excavacions en el jaciment de Minferri (Juneda, les Garrigues). Revista d'Arqueologia de Ponent 7, 161-211.

\section{GENNEP, A. van}

1909 Les rites de passage: étude systématique des rites. Éditions A. \& J. Picard. Paris.

GRUNBERG, J.M.

2013 Animals in Mesolithic burials in Europe. Anthropozoologica 48 (2), 231-253.

\section{HAMAYON, R}

2001 Nier la mort, simuler l'amour et rappeler la vie ou le traitement funéraire du gibier abattu chez les peuples chasseurs de la forêt sibériene, in BODSON, L. (Ed.). La sépulture des animaux: concepts, usages et pratiques à travers le temps et l'espace. 107-128. Colloques d'histoire des connaissances zoologiques 12. Université de Liège. Liège.

HAMILAKIS, Y.

1998 Eating the Dead: Mortuary Feasting and the Politics of Memory in the Aegean Bronze Age Societies, in BRANIGAN, K. (Ed.). Cemetery and Society in Aegean Bronze Age. 115-132. Academic Press. Sheffield.

\section{HELMER, D., GOURICHON, L. \& STORDEUR, D.}

2004 A l'aube de la domestication animale. Imaginaire et symbolisme animal dans les premières sociétés néolithiques du nord du Proche-Orient. Anthropozoologica 39 (1), 143-163.

\section{HERNÁNDEZ CARRASQUILLA, F.}

1993 Catálogo provisional de los yacimientos con aves del Cuaternario de la península lbérica. Archaeofauna 2, 231-275.

1994 Addenda al catálogo provisional de los yacimientos con aves del Cuaternario de la península Ibérica. Archaeofauna $3,77-92$.

\section{HORWITZ, L.K. \& GORING-MORRIS, L.}

2004 Animals and ritual during the Levantine PPNB: a case study from the site of Kfar Hahoresh, Israel. Anthropozoologica 39 (1), 165-178.

JANSEN, J. \& GESTEL, W.V.,

2015 Bird skull collection. http://www.skullsite.com/index.htm.

JEUNESSE, C.

2001 Les animaux dans les pratiques funéraires autochtones de la Préhistoire récente de l'Europe. Le cas du Mésolithique. Cahiers de l'Association pour la promotion de la recherche archéologique en Alsace 17, 7-34.
JING, Y. \& FLAD, R.

2005 New zooarchaeological evidence for changes in Shang Dynasty animal sacrifice. Journal of Anthropological Archaeology 24, 252-270.

KANSA, W.S., CAMPBELL, S.

2004 Feasting with the Dead? a ritual bone deposit at Domuz tepe, south eastern Turkey (c.5550 cal BC), in O'DAY, S.J. VAN NEER, W. \& ERVYNCK, A. (Eds.). Behaviour Behind Bones: The zooarchaeology of religion, ritual, status, and identity. 2-13. Oxbow Books. Oxford.

LEWIS, G

1980 Day of shining red: an essay on understanding ritual Cambridge University Press. Cambridge.

LIESAU, C., BLASCO, C., RÍOS, P., VEGA, J., MENDUIÑA, R., BLANCO, J.F., BAENA, J., HERRERA, T., PETRI A. \& GÓMEZ, J.L.

2008 Un espacio compartido por vivos y muertos: El poblado calcolítico de fosos de Camino de las Yeseras (San Fernando de Henares, Madrid). Complutum 19 (1), 97-120.

LIZCANO PRESTEL, R., CÁMARA SERRANO, J.A., RIQUELME CANTAL, J.A., CAÑABATE GUERREO, M.L., SÁNCHEZ, A. \& AFONSO MARRERO, J.A.

1991-92 El polideportivo de Martos. Producción económica y símbolo de cohesión en un asentamiento del Neolítico final en las campiñas del Alto Guadalquivir. Cuadernos de Prehistoria de Granada 16-17, 5-101.

LYMAN, R.L.

1994 Vertebrate Taphonomy. Cambridge university Press, Cambridge.

MAHER, L.A., STOCK, J.T., FINNEY, S., HEYWOOD, J.J.N., MIRACLE, P.T. \& BANNING, E.B.

2011 A Unique Human-Fox Burial from a Pre-Natufian Cemetery in the Levant (Jordan). PLoS One 6 (1), e15815.

MALLYE, J.B.

2007 Les restes de blaireau en contexte archéologique: taphonomie, archéozoologie et éléments de discussion des séquences préhistoriques. Thèse de Doctorat. Université de Bordeaux.

MANNERMAA, $K$

2008 The archaeology of wings. Birds and people in the Baltic Sea region during the Stone Age. PhD dissertation. University of Helsinki. Helsinki.

MAROTO, J., SOLÉS, A., MADURELL, J., ALBIZURI, S. \& NADAL, J.

2011 El registre fòssil del llop a Catalunya, in MASSIP, J.M. \& MAROTO, J. (Eds.). Llops i humans a Catalunya. Del passat al present. 27-42. Quaderns 29. CECB. Banyoles.

MARTÍ, M., POU, R. \& CARLÚS, X.,

1997 Excavacions arqueològiques a la Ronda Sud de Granollers, 1994. La necròpolis del Neolític Mitjà i les restes romanes del Camí de Can Grau (La Roca del Vallès, Vallès Oriental) i els jaciments de Cal Jardiner (Granollers, Vallès Oriental). Excavacions Arqueològiques a Catalunya 14 Generalitat de Catalunya. Barcelona. 
MÁRQUEZ, J.E.

2004 Muerte ubícua: sobre deposiciones de esqueletos humanos en zanjas y pozos en la prehistoria reciente de Andalucía. Mainake XXVI, 115-138.

2006 Sobre los depósitos estructurados de animales en yacimientos de fosos del Sur de la Península Ibérica, in $\mathrm{BICHO}$, N.F. (Ed.). Animais na Pre-História e Arqueologia da península Ibérica: actas do IV Congresso de Arqueologia Peninsular (Faro, 14 a 19 de Setembro de 2004). 1526. Centro de Estudos de Património. Universidade do Algarve. Faro.

MAYA, J.L.

1992 Calcolítico y Edad del Bronce en Cataluña, in UTRILLA MIRANDA, M.P. (Ed.). Aragón/Litoral mediterráneo; intercambios culturales durante la Prehistoria. Homenaje a Juan Maluquer de Motes. 515-554. Institución Fernando el Católico. Zaragoza.

MENIEL, P.

2008 Manuel d'archéozoologie funéraire et sacrificielle. Âge du Fer. Infolio. Crausaz, Suisse.

MIRÓ, J.M.

1993 Estudi de la fauna, in GARCíA ROSELLÓ, J. (Ed.). Turó dels Dos Pins. Necrópolis Ibérica. 159-161. Museu Comarcal del Maresme. Mataró.

\section{MIRÓ, C. \& MOLIST, N.}

1990 Elements de ritual domèstic al poblat ibèric de la Penya del Moro. Zephyrus 43, 311-319.

\section{MOREY, D.F.}

2010 Dogs: Domestication and the development of a social bond. Cambridge University Press. Cambridge.

MORRIS, J.

2010 Associated bone groups; one archaeologist's rubbish is another's ritual deposition, in DAVIS, O., WADDINGTON, K. \& SHARPLES, N. (Eds.). Changing Perspectives on the first millennium BC. 83-98. Oxbow Books. Oxford.

2011 Investigating animal burials. Ritual, mundane and beyond. British Archaeological Reports British series 535. Archaeopress. Oxford.

\section{MOUTON, A.}

2004 Anatomie animale: le festin carné des dieux d'après les textes hittites I. Les membres antérieurs. Colloquium Anatolicum 3, 67-92.

2005 Anatomie animale: le festin carné des dieux d'après les textes hittites II. Les membres postérieurs et d'autres parties anatomiques. Colloquium Anatolicum 4, 139-154.

\section{NIETO, A., MOYA, A., LÓPEZ, J.B. \& AGUSTÍ, B.}

2014 Offrandes ou déchets? Le cas des bovidés en contexte funéraire dans le site du bronze ancien de Minferri (Catalogne), in GARDEISEN, A. \& CHANDEZON, C. (Eds.). Equidés et bovidés de la Méditerranée antique. 53-112. Monographies d'Archéologie Méditerranéenne, Horssérie $n^{\circ} 6$ Arles.
ONAR, V., VELLI, O. \& OWEN, P.R.

2005 Morphometric Examination of Red Fox (Vulpes vulpes) from the Van-Yoncatepe Necropolis in Eastern Anatolia. International Journal of Morphology 23 (3), 253-260.

\section{PALOMO, A. \& RODRÍGUEZ, A.}

2004 Can Roqueta II (Sabadell, Vallès Occidental). Tribuna d'Arqueologia 2000-2001, 77-98.

PINGEL, V., SCHUBART, H., ARTEAGA, O., ROOS, A.M. \& KUNST, M.

2003 Excavaciones arqueológicas en la ladera sur de Fuente Álamo. Campaña de 1999. Spal 12, 179-229.

POPLIN, T.

1976 Remarques théoriques et pratiques sur les unités utilisées dans les études d'ostéologie quantitative, particulièrement en archéologie préhistorique, in BARRAL, L. (Ed.). Problèmes d'interprétation ethnographique des vestiges osseux. 1-16. IXème Congrès UISPP. Nice.

POZO, M., KUNTER, M., MEDINA, J.A., LIESAU, C., CASAS, J., SCHUBART, H., PINGEL, V., TRESSERRAS, J. \& HÄGG, I.

2004 Studien zum Grab 111 der Nekropole von Fuente Álamo (Almería). Madrider Mitteilungen 45, 57-146.

REINOLD, J.

2005 Notes sur le monde animal dans le funéraire néolithique du Soudan. Revue de Paléobiologie 10, 107-119.

ROVIRA, M.C

2006 El bronze inicial a Catalunya des de la perspectiva metal·lúrgica. Cypsela 16, 135-145.

RUSSELL, N

2010 Navigating the Human-Animal Boundary. Reviews in Anthropology 39, 3-24.

2012 Hunting sacrifice at Neolithic Çatalhöyük, in PORTER, A \& SCHWARTZ, G.M. (Eds.). Sacred Killing: The Archaeology of Sacrifice in the Ancient Near East, 79-95. Eisenbrauns. Warsaw.

SERJEANTSON, D. \& MORRIS, J.

2011 Ravens and crows in Iron Age and Roman Britain. Oxford Journal of Archaeology 30 (1), 85-107.

\section{SCHWARTZ, M}

2007 Status, Ideology, and Memory in Third-millennium Syria: "Royal" Tombs at Umm el-Marra, in LANERI, N. (Ed.). Performing Death. Social analyses of funerary traditions in the ancient Near East and Mediterranean. 39-68. Oriental Institute Seminars 35. The Oriental Institute of the University of Chicago. Chicago.

\section{YALDEN, D.W}

2002 Place-name and archaeological evidence on the recent history of birds in Britain. Acta Zoologica Cracoviensia 45 (special issue), 415-429. 